IMAFRONTE- $\mathrm{N}^{\mathrm{o}} 27.2020$, pp. 1-26

\title{
LA PLATERÍA COMO MEDIO DE CONTAR LA HISTORIA: EL CONTEXTO DE SANTIAGO DE COMPOSTELA ENTRE EL SIGLO XIX Y EL XX A TRAVÉS DE LAS OBRAS DE RICARDO MARTÍNEZ
}

\section{PLATELY AS A MEANS OF TELLING THE STORY: THE CONTEXT OF SANTIAGO DE COMPOSTELA BETWEEN THE XIX AND XX CENTURIES THROUGH THE WORKS OF RICARDO MARTÍNEZ}

\author{
ANA PÉREZ VARELA \\ Universidad de Santiago de Compostela
}

Recibido: 14-01-20 / Aprobado: 23-04-20

\section{RESUMEN}

Acostumbramos a decir que las obras de arte son hijas de su tiempo. En este artículo exploramos el contexto histórico-artístico de la Compostela del tránsito del siglo XIX al XX, una época efervescente a menudo olvidada por los estudios, a través de una serie de obras de platería del célebre Ricardo Martínez. Siendo las artes suntuarias un elemento clave de las grandes lagunas historiográficas del arte compostelano, a lo largo de este texto pretendemos demostrar cómo dimensiones como la platería y otros oficios artísticos de Santiago pueden contribuir a construir su discurso historiográfico.

PALABRAS CLAVE: Platería, Santiago de Compostela, siglo XIX, regalos diplomáticos, exposiciones regionales.

\section{ABSTRACT}

We're used to saying that works of art are the mirror of History. In this paper, we explore the historical and artistic context in Compostela between the nineteenth and twentieth century, a vibrant epoch often forgotten in the studies, throughout a series of pieces of silversmithing by the artist Ricardo Martínez. Being the sumptuary arts a key element, quite ignored by the historiography of the art from Compostela, this text aims to demonstrate how artistic fields like silversmithing and other artistic Artsand-Crafts from Santiago can contribute to build its historiographical state of art. 
KEY WORDS: Silversmithing, Santiago de Compostela, nineteenth century, diplomatic gifts, regional exhibitions.

\section{INTRODUCCIÓN: UN CONTEXTO EXTRAORDINARIO}

El último cuarto del siglo XIX estuvo marcado en Compostela por un hecho extraordinario que cambió el devenir de la ciudad. Lo que conocemos como segunda inventio fue el hallazgo de los restos del apóstol Santiago en la Catedral, que llevaban tres siglos perdidos. La tradición afirma que el arzobispo Juan de Sanclemente y Torquemada (1587-1602) ocultó los huesos para evitar el saqueo de las tropas de Francis Drake, que habían desembarcado en A Coruña en 1589. Cuando el prelado murió, y sin conocimiento por parte del Cabildo de dónde había escondido los restos, éstos se perdieron, y se suponían ocultos en algún lugar bajo la capilla mayor ${ }^{1}$. De este modo, la Iglesia compostelana se enfrentaba a finales del siglo XIX a una situación complicada, habiéndose puesto en entredicho y mitificado la presencia del cuerpo. La imposibilidad de contemplar un sarcófago, una lápida o cualquier indicio material perjudicaba gravemente la credibilidad de la fábrica, situación que se ve claramente reflejada en la literatura de viajes de la época².

Fue el arzobispo Miguel Payá y Rico (1874-1886) el responsable de encargar una expedición que recuperase tanto el cuerpo como los restos arqueológicos del sepulcro del siglo I, sobre el que se había ido construyendo la basílica desde sus primitivas versiones de Alfonso II y Alfonso III, hasta la gran fábrica del arzobispo Diego Gelmírez (11001140). Esta decisión está transparentando en Compostela el contexto general del catolicismo finisecular, en el que la Iglesia pasó de ver la ciencia moderna como una enemiga para emplearla en su beneficio, convirtiéndola en herramienta legitimadora de sus verdades. Como señaló Requejo Alonso (2005: 143-144), la ciencia fue "la forma de acercarse a los ambientes más hostiles a la religión al adoptar una metodología moderna de interpretación, pero también la forma de acercarse a la sociedad dando la apariencia de quien no teme a la ciencia ante la seguridad de sus creencias". La Teología descubrió que la ciencia moderna podía "testimoniar, confirmar y demostrar, a través de objetos tangibles, aquellas verdades que ateos y anticatólicos ponían en duda"3. Encontrar el

\footnotetext{
${ }^{1}$ Ésta es la historia que se repite en las fuentes de época, como Fita y Fernández Guerra (1880: 80); o López Ferreiro (1898-1909: tomo VIII, 308-321).

${ }^{2}$ Pese a que las guías y obras descriptivas de la época surgidas del círculo catedralicio (Villaamil y Castro, 1866: 63-64; López Ferreiro, 1877: 3; o Zepedano Carnero, 1870: 20-27) afirmaban la existencia del cuerpo, los viajeros e historiadores extranjeros se mostraban recelosos. Sirvan como ejemplo las dudas de Borrow (1996: 316-317).

${ }^{3}$ En 1883, en Roma se abrieron los Archivos Vaticanos a los investigadores. Además, se promovió la excavación de las catacumbas, apoyando incondicionalmente a los arqueólogos, se creó la cátedra de Paleografía e Historia Comparada, y se abrió el Instituto de Arqueología Cristiana (Requejo Alonso, 2005: 143-144).
} 
sepulcro primitivo, los restos del siglo I, era crucial en la lucha ante los escépticos que ponían en duda su veracidad.

Las excavaciones fueron dirigidas por el fabriquero Antonio López Ferreiro y el canónigo José María Labín Cabello. Tras haber hallado los restos del edificio funerario, la noche del veintiocho al veintinueve de enero de 1879 se descubrió en el trasaltar un tosco sepulcro con los restos de tres esqueletos humanos ${ }^{4}$. El hallazgo dio lugar a un proceso de certificación por parte de la curia vaticana que cristalizó en la bula Deux Omnipotens del pontífice León XIII, el uno de noviembre de 1884, que legitimaba las reliquias y animaba a los fieles a peregrinar a Santiago. La ratificación científica por parte de los catedráticos pertinentes ${ }^{5}$ en el contexto positivista que hemos comentado, queda ejemplificada en estas palabras del Boletín del Arzobispado: "Quedan pues, para siempre, sepultadas las maliciosas dudas que lastimando las seculares tradiciones de un pueblo habia suscitado la falsa crítica, despreciadora de tradiciones y aún de probados acontecimientos históricos"6.

El hallazgo hizo resurgir a la fábrica compostelana de las cenizas en las que la había sumido el precario siglo XIX, revitalizando fervorosamente las peregrinaciones desde el Año Santo Especial de $1885^{7}$. A ello se unió la continua revalorización de la Catedral como joya de la arquitectura medieval y el contexto de impulso turístico y ferviente interés por los estilos históricos ${ }^{8}$. El espíritu romántico que impregnó Europa en el siglo XIX estuvo caracterizado por la autoafirmación que cada territorio hizo de sus valores patrios: sus costumbres, su lengua, sus tradiciones, sus valores culturales y su arte. El Galeguismo supo aprovechar los hitos de la historia del arte compostelano ${ }^{9}$ y, partiendo del interés general por estos monumentos, consiguió crear un discurso de identidad propia basado en la idea de promoción del patrimonio cultural —artístico, lingüístico, literario, costumbrista, etc. - y la ligazón de estas manifestaciones con épocas pasadas de esplendor, como el arte medieval de la época de Gelmírez. Las publicaciones de la época transparentan la construcción identitaria de Galicia a través de su historia cultural y artística. Autores como Murguía escribieron sobre la utilidad del folclore como fuente histórica y como realidad llamada a prestar «grandísimos servicios a Galicia y a su historia» ${ }^{10}$.

Dentro de este contexto extraordinario marcado por la segunda inventio y la revalorización patrimonial, este artículo presenta tres obras emblemáticas realizadas por

\footnotetext{
${ }^{4}$ Archivo de la Catedral de Santiago (en adelante ACS). Actas Capitulares. Libro 79 (IG 634), cabildos del 31 de enero de 1879, ff. 214r-214v; y 1 de febrero de 1879, ff. 214v-215r.

${ }^{5}$ Fueron Antonio Casares, rector de la Universidade de Santiago y catedrático de Farmacia, y los doctores Freire Barreiro y Sánchez Freire, catedráticos de Medicina y Cirugía. Además, el proceso también contó con la presencia de Aureliano Fernández Guerra y Fidel Fita, académicos de la Historia (Guerra Campos (1982: 14) y Suárez Otero (2014: 113).

${ }^{6}$ Boletín del Arzobispado de Santiago, 7 de agosto de 1884: 17.

${ }^{7}$ Para los Años Santos de las últimas décadas del XIX, véase Rodríguez Lago (1995: 205-226). Para ampliar sobre la reactivación del culto jacobeo, véase Pombo Rodríguez (1999: 157-196). Para el análisis de las peregrinaciones en el siglo XIX, véase Pugliese (1999: 37-62).

${ }^{8}$ En este sentido, es importante recalcar que la Catedral fue declarada monumento nacional el 22 de agosto de 1896.

${ }^{9}$ Para ampliar sobre esta cuestión, véase Mateo Sevilla (1991).

${ }^{10}$ Galicia Diplomática, 9 de febrero de 1884: 219-220; y 20 de febrero de 1884: 235-236.
} 
el célebre platero Ricardo Martínez ${ }^{11}$ que ejemplifican la época próspera que vivieron los oficios artísticos, y en concreto la orfebrería, a partir de esta realidad. Estas tres piezas se relacionan de modo muy claro con tres aspectos fundamentales de la construcción de la historia de Compostela entre el siglo XIX y el XX: la promoción del Apóstol como valor indiscutible de la ciudad, el contexto celebrativo y diplomático que motivó la aparición de sus restos, y la revitalización de las artes aplicadas a través de la fiebre expositiva y la conjunción de arte e industria.

\section{EL APÓSTOL COMO EMBLEMA UNIVERSAL: LA URNA DE LAS RELIQUIAS DE SANTIAGO}

«El presente se veía como reflejo del pasado y a éste se le daba vocación de futuro [...]. De lo que se trataba ahora era de recuperar el viejo impulso de la peregrinación y renovar el sentimiento religioso, y de paso, obtener beneficios económicos y políticos. Había que diseñar cuidadosamente la puesta en escena, y lo cierto era que la ciudad se prestaba a ello. De esta manera, el peregrino no sólo podía inflamar su aliento religioso y disfrutar de la proximidad del Apóstol con todo un protocolo puesto a su servicio, sino de una ciudad que era todo un halago por su capacidad de seducción visual $[\ldots]$...

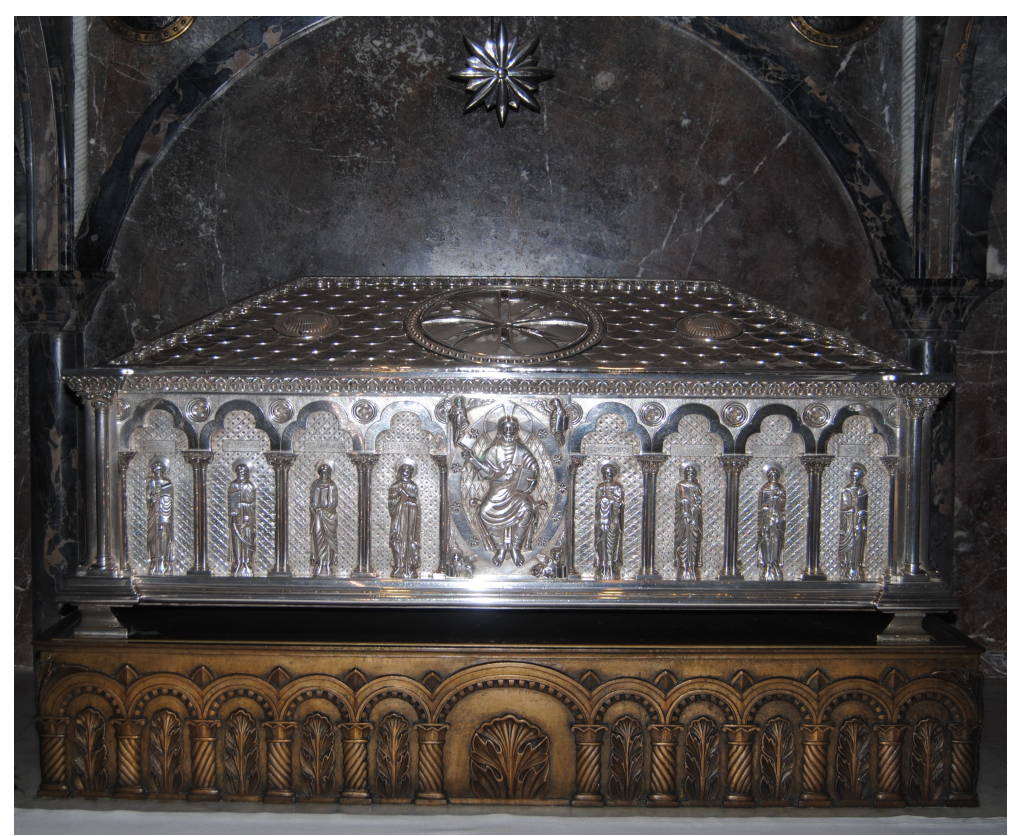

FIGURA 1: OBRADOR DE JOSÉ LOSADA. URNA APOSTÓLICA. 1884-1891. CATEDRAL DE SANTIAGO DE COMPOSTELA.

Estas palabras de Rosende Valdés (2013: 29) ejemplifican a la perfección la estrategia legitimadora del culto puesta en marcha no sólo por el contexto catedralicio.

${ }^{11}$ Sobre este platero, véanse los estudios de Pérez Varela (2018a, 2018b y 2019). 
sino por la propia ciudad y sus instituciones civiles. El Apóstol, cuyo cuerpo había sido recién hallado, era un valor que promocionar y una posesión de la cual presumir.

La primera obra de platería a la que debemos referirnos en este texto, indiscutiblemente, es simbólicamente la más importante de la catedral compostelana y constituye su epicentro, custodiando la posesión más preciada: los restos de Santiago el Mayor. La urna apostólica [figura 1] ${ }^{12}$ se encargó tras la ratificación de las reliquias con la mencionada bula papal, en 1884, al obrador del platero de la Catedral, José Losada ${ }^{13}$. La obra fue llevada a cabo por sus oficiales, Ricardo Martínez y Eduardo Rey, ya que el maestro hubo de ingresar en el manicomio de Conxo, donde murió en 1887. Fue Martínez quien, además de recoger su testigo como platero de la fábrica y hacerse cargo de su obrador, remató la urna en 1891 realizando la repisa broncínea sobre la que se apoya la obra $^{14}$.

El diseño del proyecto corrió a cargo de López Ferreiro, que ideó una obra emblemática en todos los sentidos, y que refleja de un modo muy especial el pensamiento estético de la época. El fabriquero, encargado de remodelar toda la cripta jacobea, hizo uso del historicismo como principal elemento de su pensamiento artístico, no solo como una evocación estética sino también con una intención histórica. Para ello recurrió a dos momentos clave: el siglo I y el siglo XII. Para la cripta, supo conjugar inteligentemente los restos arqueológicos que certificaban científicamente el origen romano del monumento sepulcral — dejando a la vista los sillares a soga y tizón- con un aparato arquitectónico románico que ligaba la construcción a dos aspectos fundamentales: por un lado, devolvía al núcleo catedralicio su estilo propio, el de la época de Gelmírez ${ }^{15}$, evocando la etapa gloriosa de la fábrica que él quería emular; por otro, hacía una interpretación literal del término arca marmarica, entendido por él como "arcos de mármol" al que se refirieron los textos que, a partir del siglo VI, afirmaban la presencia del cuerpo del Apóstol en Galicia ${ }^{16}$. De esto modo, está legitimando las fuentes escritas que los escépticos rechazaban ${ }^{17}$. En palabras de Mera Álvarez (2011: 46):

\footnotetext{
12 Plata en su color y bronce. 1884-1891. Fundida y cincelada. Urna: $50 \mathrm{~cm}$ (altura), $130 \mathrm{~cm}$ (anchura), 70 (fondo); repisa: $20 \mathrm{~cm}$ (altura), $130 \mathrm{~cm}$ (anchura). Inscripciones: "SE HIZO EN LOS TALLERES DE JOSÉ LOSADA. SANTIAGO / AÑO MDCCCLXXXVI".

13 José Losada fue artífice oficial de la catedral de Santiago entre 1853 y 1886. Sobre su vida y obra, véase Pérez Varela (2018c: 675-696 y 2019: 131-141).

${ }^{14}$ ACS. Actas Capitulares. Libro 80 (IG 635), 13 de febrero de 1891, ff. 276r-276v.

${ }^{15}$ El estilo escogido para hilvanar su discurso, que él mismo denomina como "románico bizantino", es toda una declaración de intenciones. Atienden a esa elección tres razones: ser "el estilo propio de la Catedral"; el más "sobrio, severo y reposado" de la historia del arte; y un estilo "originalmente nacido y evolucionado en el seno de la Iglesia según los ideales cristianos" (López Ferreiro, 1891: 11-12).

${ }^{16}$ Entre la lista de fuentes escritas que fueron forjando la creencia de que el cuerpo del Apóstol estaba enterrado en tierras gallegas encontramos: el Breviarium Apostolorum (finales del siglo VI); los textos de Máximo de Zaragoza (ca. 571); el himno atribuido a san Isidoro de Sevilla De ortu et obitu patrum (570636); los textos de Beda el Venerable y Adhelmo de Malmesbury — ambos de la segunda mitad del siglo VII-, los comentarios de Beato de Liébana (ca. 776-786); el himno visigótico O dei verbum patris (ca. 786); los martirologios de Floro de Lyon (ca. 808-838) y Adón (ca. 860); y la polémica Epístola Leonis o la Carta a los Vándalos, Godos y Romanos, de dudosa datación. Estas fuentes fueron creando la idea de que Santiago el Mayor había predicado en Hispania, y que estaba enterrado frente al "mar británico".

17 El texto de Duchesne (1900: 145-179), apoyado por el círculo bolandista y Delehaye, afirmó rotundamente que no existía ningún tipo de evidencia histórica que señalase la predicación de Santiago en Hispania y mucho menos su traslatio, achacando a la historiografía española una falta absoluta de rigor y
} 
"La vinculación de un estilo arquitectónico con una representación simbólica, bien un sentimiento, como la ya conocida relación entre la arquitectura medieval y la religiosidad y espiritualidad, bien la rememoración de un pasado glorioso, adquiere en estos momentos, y más en la catedral de Santiago, unas especiales connotaciones".

La misma dualidad simbiótica se observa en la propia urna, donde dialogan el siglo I y el XII en perfecta conjunción. El referente formal es la tabula retro altaris que Gelmírez colocó hacia $1137^{18}$, un retablo de plata de tipo políptico, que Fernández Sánchez y Freire Barreiro (1880: 44) describieron como "una de las más interesantes [obras] de la orfebrería de la Edad Media". Esta pieza, primicia hispánica en el género, contaba con una forma pentagonal a modo de frontón, y estaba decorada con el relieve del Salvador en el centro, sedente y enseñando las llagas; y los doce Apóstoles y la Virgen a cada lado en dos registros, organizados por arcos trilobulados entrepilastrados. Perdida en la reforma barroca del presbiterio, la conocemos gracias a un dibujo del célebre Informe del fabriquero José Vega y Verdugo (1657) ${ }^{19}$, documento que motivó dicha reforma en el siglo XVII ${ }^{20}$, y que nos da dos versiones de la obra. La primera es la original, ya descrita, mientras que la segunda es la del aspecto que tendría en tiempos del propio Vega y Verdugo, con las modificaciones realizadas en 1560 por el platero vallisoletano Juan Álvarez (Taín Guzmán, 2008: 208-210). El resultado de éstas fue su encajamiento en una estructura rectangular de madera con friso decorado y ceñida en sus vértices por columnas de orden gigante. Estas modificaciones hicieron que la obra gelmiriana perdiese su naturaleza tipológica de retablo y pasase a ser un arca, por lo que muchos autores confundieron esta estructura con el sepulcro que albergaba en su interior los restos apostólicos ${ }^{21}$.

Precisamente, este tipo de arca y distribución morfológica (caja rectangular, columnas de orden gigante y friso decorado) fue la que adoptó López Ferreiro para el diseño de la urna actual, componiéndola como una sucesión de arcadas lobuladas acogiendo dieciocho figuras distribuidas flanqueando la Maiestas Domini en una mandorla oval. Además, añadió una cubierta a cuatro vertientes adornada con un fondo de escamas de pez, con el crismón en el centro. El canónigo entendió así la forma pentagonal desglosada en un frontal y una cubierta, aplanada ésta para poder ser vista de frente. Lo que está haciendo con esta modificación es conjugar el retablo de plata románico con un sarcófago paleocristiano, que él entendía como el posible enterramiento de Santiago en el siglo I - a pesar de que hoy lo entendemos como anacronismo-. El lienzo de Modesto Brocos, Las Tradiciones del Apóstol Santiago en Galicia (ca. 1897), realizado en el mismo contexto histórico y simbólico del redescubrimiento de los huesos,

credibilidad. Esta línea fue apoyada en España por Pérez de Urbel (1952), Vives (1956) y Sánchez Albornoz (1971). Por su parte, el bando jacobeo, liderado por López Ferreiro, fue seguido por varios historiadores entre los que destacan Fita y Fernández Guerra (1880), García de Villada (1928), Portela Pazos (1953), Elorduy (1954), Carro García (1954), y Guerra Campos (1982).

18 Sobre la tabula retro altaris de Gelmírez, con bibliografía actualizada, véase Yzquierdo Peiró (2017: 255).

${ }^{19}$ Fue editado en dos ocasiones (Sánchez Cantón, 1956: 7-52, y Castillo Oreja, 2001: 207), aunque con anterioridad, Zepedano y Carnero (1870: láminas 1 y 3) y López Ferreiro (1898-1909: tomo IX, ap. XXII, 110-119), ya habían hecho uso del documento con la reproducción de algunos de sus dibujos y fragmentos.

${ }^{20}$ Sobre la remodelación barroca del presbiterio, véase Taín Guzmán (2008: 200-216).

${ }^{21}$ Se conservan testimonios que así lo señalan, como el obispo armenio Mártir de Arzendjan (1429); Corsini y Lorenzo Magalotti sobre el viaje de Cosme III de Medici (1669); o Domenico Laffi (1673). Sobre estas fuentes, véase Taín Guzmán (2006: 604). 
ilustró la primera inventio con un curioso sarcófago paleocristiano, con un frente de estrígiles, hecho que ya señaló como curioso Otero Túñez (1970: 393-394). Seguramente el pintor pudo ver ejemplos al respecto en su estancia en Roma. El hecho de que la cubierta sea prácticamente idéntica a la urna actual nos hace pensar que Brocos se inspiró en la obra de Martínez y Rey. La filiación paleocristiana de la urna quedaría todavía más subrayada con esta referencia arqueológica de Brocos que demuestra una intención de ambientar la escena sagrada de la forma más naturalista y veraz posible, entendiendo el paleocristiano de forma anacrónica como una referencia válida para el siglo I, al igual que López Ferreiro.

La iconografía de la obra, de sobria inspiración mateana, es otro aspecto interesante, al presentar cuatro figuras clave relacionadas con Santiago, tales como los discípulos Teodoro y Atanasio, el varón apostólico Torcuato ${ }^{22}$ y su madre, santa María Salomé ${ }^{23}$. Algunas de estas representaciones no tenían especial desarrollo en tiempos de Gelmírez ${ }^{24}$, pero en el siglo XIX se explican en este contexto legitimador.

El contexto celebrativo de la aparición de los restos se selló con la colocación de las reliquias en la urna el día de la octava del Corpus de 1886, veintisiete de junio, exponiéndola en uno de los altares que se levantarían en el claustro ${ }^{25}$ y sacándola en procesión tras una multitudinaria ceremonia a la que acudieron las personalidades eclesiásticas, universitarias y políticas más importantes de la ciudad ${ }^{26}$. En 1891, con la

\footnotetext{
${ }^{22}$ No tenemos una idea clara sobre la primera fuente que menciona los discípulos de Santiago, y los datos se vuelven más confusos teniendo en cuenta que suelen mezclarse y confundirse con los llamados "Varones Apostólicos". La Leyenda Dorada menciona nueve discípulos, de los cuales dos permanecieron en Hispania predicando cuando el Apóstol regresó a Jerusalén, pero no da sus nombres. Tampoco el de los discípulos que devuelven su cuerpo a la Gallaecia (Varazze, 1987: 397). Según Castellá Ferrer (1610: ff. 134r y 142v), y citando al obispo Sampiro de Astorga, estos discípulos fueron Calocero, Basilio, Pío, Crisógono, Teodoro, Atanasio y Máximo. El escritor señaló a Teodoro y Atanasio como los dos que recibieron sepultura con él, citando la polémica Espistola Leonis. López Ferreiro (1877: 11-12) citó asimismo el Códice Calixtino, donde se aludía a Atanasio, Teodoro, Torcuato, Segundo, Indalecio, Tesifonte, Eufrasio, Cecilio y Hesiquio. Estos siete últimos han sido identificado tradicionalmente como los "Varones Apostólicos", considerados como mandados por san Pedro y san Pablo, que habrían evangelizado el sur de España (Cebrián Franco, 1998: 4). Según la línea historiográfica opuesta a considerar la presencia de Santiago en Hispania, la tradición jacobea habría plagiado estas figuras para apoyar su causa (Guerra Campos y Cebrián Franco, 2003: 499, nota 82). Esta misma línea rechaza también la traslatio y por consiguiente la existencia de los discípulos, tildándolos de una "invención medieval". Sin embargo, la aparición en 1988 de una lápida con la inscripción "A $\Theta A N A \Sigma I O \Sigma$ " en las excavaciones arqueológicas del mausoleo del Apóstol significó una baza muy importante para el bando defensor en la lucha historiográfica sobre la cuestión jacobea (Millán González-Pardo, 1990: 18-20). Para ampliar sobre los "Varones Apostólicos", véase García de Villada (1928: tomo I, 151).

${ }^{23}$ En el XI Congreso de la Sociedad Española de Emblemática (Santiago de Compostela, 2017) Gómez Darriba presentó una comunicación al respecto de la figura de María Salomé, cuyas actas están próximas a publicarse, y que constituirá una referencia obligada para analizar la iconografía de la santa y su configuración en la Compostela medieval en relación al interés de la iglesia gelmiriana por rendirle culto. Agradecemos al autor su amabilidad por la consulta de su manuscrito.

${ }^{24}$ Sí lo tuvo, al parecer, Santa María Salomé. Según Gómez Darriba, la promoción del culto a la madre de Santiago podría ser inédito de Compostela, teniendo origen en el siglo XII, en el contexto en el que el arzobispo Gelmírez trataba de legitimar las reliquias jacobeas y posicionar a la sede de Compostela como una de las más importantes de la Cristiandad. Nos remitimos de nuevo al mismo manuscrito de la nota anterior.

${ }^{25}$ ACS. Actas Capitulares. Libro 80 (IG 635), cabildo del 28 de junio de 1886, ff. 111r-111v.

${ }^{26}$ Ibídem. Acta de colocación de los restos apostólicos en la urna, ff. 117r-119v.
} 
colocación de la repisa de bronce, se festejó la culminación de la obra, instalando la urna definitivamente en la cripta ${ }^{27}$.

El conjunto de la obra resulta un ejemplo perfecto de la mentalidad estética del momento, dominada por el historicismo, el anhelo de la época medieval y la vuelta a su pureza y sobriedad. Tanto las obras de los historiadores autóctonos como en los libros de viajes, tan característicos del periodo que nos ocupa, dejaron por escrito sus quejas continuas sobre las reformas barrocas, que habían "desfigurado la fábrica bizantina" (Fernández Sánchez y Freire Barreiro, 1880: 45). En esta literatura, el estilo medieval es el que inspira y eleva la contemplación estética: "ninguna [reforma está] en armonía con la fábrica primitiva que inspiró el sueño cristiano" (Fernández Sánchez y Freire Barreiro, 1880: 119-120), alabando especialmente a la pétrea Gloria mateana, el alzado de las naves y la portada de Praterías, única fachada románica. Además, el románico gallego es visto por los extranjeros como un estilo propio con características autóctonas. Según Hartley (Garrido, 1994: 303-304), "el románico se mantuvo en Galicia durante cinco siglos y fue empleado por los arquitectos gallegos hasta el siglo XV, mucho después de que se dejase de utilizar en el resto de España", tomando un cariz muy localista y según ella, anclado en imaginarios sumamente poéticos y elementos de raíz celta.

La cripta de López Ferreiro hace uso del valor patrio del románico como medio para volver a un pasado glorioso, tanto histórico, como estético. No cabe duda de que estamos ante una obra excepcional y un lugar sin comparación. El locus más sagrado de la basílica jacobea no conserva solamente los supuestos restos del Apóstol, sino que posee un simbolismo territorial intrínseco. Es ese pequeño espacio de tierra el que tuvo contacto directo con los discípulos de Santiago, que trajeron su cuerpo desde Jerusalén y escogieron este lugar para enterrarlo. Los restos arqueológicos del edículo sepulcral actúan, como había dicho López Ferreiro (1891: 34), como auténticos "cimientos históricos de nuestra fe", y de ese modo simbólico cimientan el epicentro irradiador de un culto, de una cultura de peregrinación, de una ciudad, de un fenómeno único. Y refulgente en el corazón de la cripta, como brillante contenedor del milagro, reposa la urna de Losada, Martínez y Rey, que en palabras de Vidal Rodríguez, "guarda las cenizas veneradas del Evangelizador de España, [y que] parece guardar también en cierto modo los gérmenes de la fe que la ha hecho grande y gloriosa" (Vidal Rodríguez, 1924: 93).

\section{EL CONTEXTO CELEBRATIVO: LOS REGALOS DIPLOMÁTICOS}

En segundo lugar queremos referirnos a una tipología que se generalizó a partir de finales del siglo XIX y que en Compostela fue promocionada y extendida, en parte, gracias al espíritu celebrativo que inundó la ciudad tras esta segunda inventio. Nos referimos a las obras que funcionaban como regalos diplomáticos: placas, láminas,

\footnotetext{
27 "Nuestro Excmo. Sr. D. José Martín de Herrera quiso que este monumento elevado a la memoria del Patrón de España saliera de la oscuridad en que se hallaba para llamar la atención de nuestro época, y el día 2 de mayo de 1891, fecha inmemorable para nuestra nación, puso el sello a las obras de la cripta y consagró la urna marmórea a la que con destino á aquel lugar le bajó del altar mayor". Gaceta de Galicia, 25 de julio de 1894: 2
} 
cuadros, libros y otras piezas conmemorativas entregadas a los personajes ilustres e instituciones en homenajes y actos protocolarios.

Dentro de este género podemos distinguir, en primer lugar, las obras encargadas por la propia Catedral conocidas como "cuadros de ofrenda". Esta tipología constituye, de hecho, el encargo más común pedido al platero oficial de la Catedral a lo largo de su historia. Ricardo Martínez trabajó para la fábrica durante casi cuarenta años (1886-1924) y a lo largo de esta trayectoria realizó numerosos ejemplos de estas piezas. Solían ser pequeños cuadros de madera o terciopelo con relieves de plata del Apóstol que generalmente presenta la iconografía de Santiago en la batalla de Clavijo y, más adelante, como peregrino. Servían al propósito de intercambio de regalos diplomáticos con ciertas personalidades nobiliarias, eclesiásticas y del gobierno civil, que venían a presentar la ofrenda anual en representación de la Corona (Bouza Brey, 1962: 22) el 25 de julio, día del Apóstol, y el 28 de diciembre, día de su Traslación. La cantidad de cuadros de ofrenda encargada por la fábrica en el siglo XX es cuantiosísima y supera con creces la centena. Desgraciadamente, al ser pensados para regalar hemos podido ubicar muy pocos, ya que las facturas expresan "para el señor obispo", "para su majestad el Rey", "para el señor secretario de", "para el señor gobernador de la provincia", sin dar nombres concretos que nos puedan ayudar a seguirles la pista.

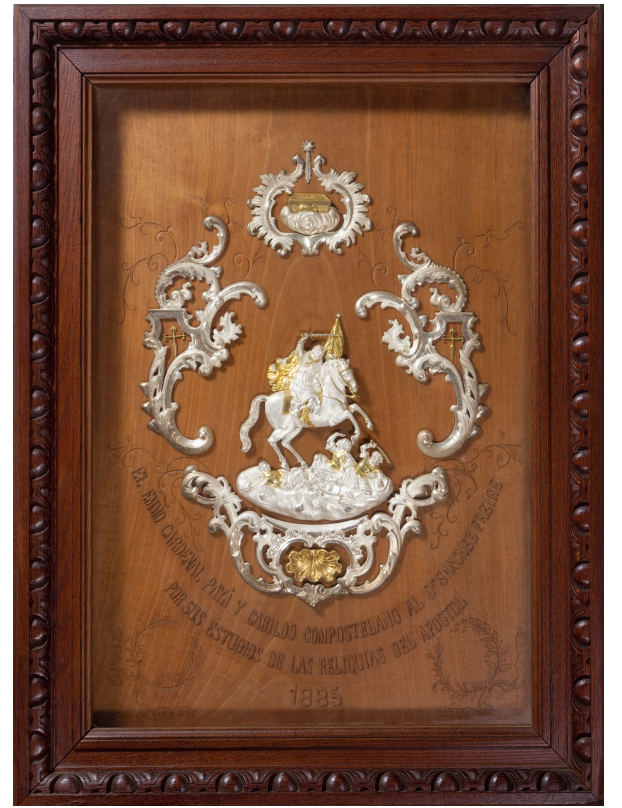

FIGURA 2: ATRIBUIDO A RICARDO MARTÍNEZ. CUADRO DE OFRENDA. 1885. CATEDRAL DE SANTIAGO DE COMPOSTELA.

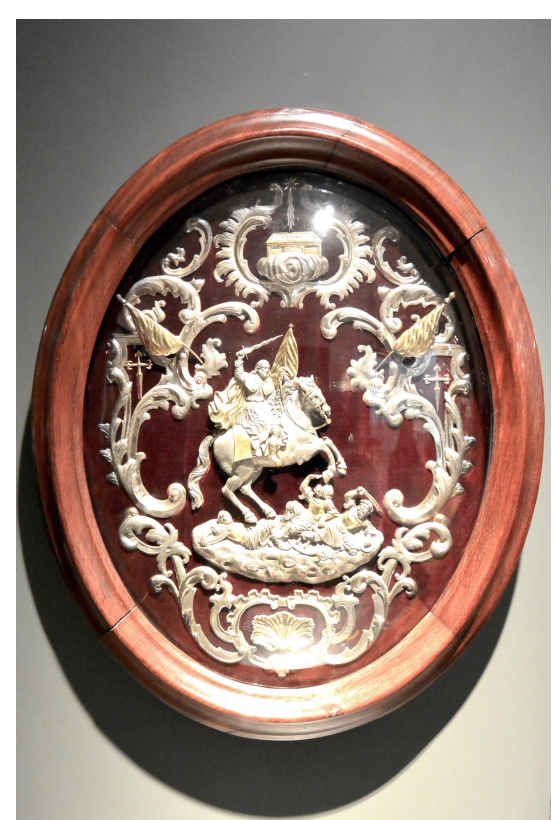

FIGURA 3: ATRIBUIDO A RICARDO MARTÍNEZ. CUADRO DE OFRENDA. CA. 1885. MUSEO DAS PEREGRINACIÓNS E DE SANTIAGO.

En la propia catedral compostelana sólo se conserva uno [figura 2] ${ }^{28}$. Data de 1885 y fue un regalo del Cabildo al doctor Sánchez Freire por examinar las reliquias apostólicas

${ }^{28}$ Plata en su color y sobredorada. 1885. Moldeada y cincelada. Inscripción (en la madera): "EL EXMO. 
y confirmar su autenticidad ${ }^{29}$. En dicho año se contabilizó en las facturas de la Catedral el pago a José Losada por un cuadro del Apóstol para "el señor gobernador", pero no se registró ninguno para este médico en las cuentas de dicho platero ${ }^{30}$. El Museo das Peregrinacións e de Santiago custodia dos obras que hemos identificado como cuadros de ofrenda. El primero de ellos [figura 3$]^{31}$ está en consonancia evidente con el catedralicio para Sánchez Freire - creemos que es del mismo autor-, con la misma moldura envolvente de orejas y ces en curva y contracurva, así como las representaciones convencionales de la urna bajo estrella arriba y una venera vegetal abajo. El segundo ${ }^{32}$ presenta ciertas características distintas, como el gran marco de laurel que ciñe al Matamoros, y está fechado en el reverso en 1867.

De todos éstos, el único que podemos relacionar de forma posible con Ricardo Martínez es el del doctor Sánchez Freire, conservado en la fábrica. La fecha de 1885 y el hecho de que no aparezca relacionado como obra de Losada en sus facturas nos hacen pensar que pudo ser un encargo a nuestro platero, quien ya se encontraba trabajando para la Catedral en la urna junto a su maestro, pero no entregaba todavía a la Catedral las facturas detalladas del platero oficial. Si aceptamos esta atribución, el primer ejemplar del Museo debería ser también suyo, por evidentes similitudes. El segundo del mismo centro, por la fecha del reverso, estaría relacionado de forma casi inequívoca con José Losada, platero de la fábrica en aquel momento y quien hacía todos los cuadros de ofrenda ${ }^{33}$.

Tenemos constancia, por sus facturas, de que Martínez realizó cuadros de ofrenda para el monarca Alfonso XIII, cuando éste vino a realizar personalmente la ofrenda nacional los años santos de $1904^{34}$ y $1909^{35}$. Afortunadamente, las descripciones en prensa y las fotografías halladas en el archivo personal del platero nos han permitido

CARDENAL PAYÁ Y CABILDO COMPOSTELANO AL DR SÁNCHEZ FREIRE / POR SUS ESTUDIOS DE LAS RELIQUIAS DEL APÓSTOL / 1885". Sobre esta obra, véase Yzquierdo Peiró (2017: 109-110).

${ }^{29}$ Además de la inscripción que aparece en el cuadro, podemos comprobar esta decisión del Cabildo, sin especificar a quién se encargan dichos cuadros, en ACS. Actas Capitulares. Libro 80 (IG 635), cabildo del 27 de octubre de 1885, ff. 92r-93r.

${ }^{30}$ ACS. Cuentas (IG 584), 1885.

31 Ficha en CERES núm. D-1120. Plata en su color y sobredorada, y terciopelo. Fecha desconocida. Cincelada, repujada, grabada. $50 \mathrm{~cm}$ (altura), $42 \mathrm{~cm}$ (anchura). Ingresó en el museo por compra el 08/05/2013.

32 Ficha en CERES núm. D-887. Plata en su color y sobredorada, y terciopelo. 1867. Cincelada, repujada, grabada. $26 \mathrm{~cm}$ (altura), 17,50 cm (anchura). Inscripciones: "C. / 366 / El Emo. y Excmo. Sr. Cardenal Arzobis / po de Santiago bendijo esta Sta. Ymagn. Del Apóstol Santiago el día 28 de Julio de / 1867. = Concede 100 días de Yndulgas. por / cada Padrenuestro y Ave María que se / rece delante de esta Sta. Ymagn. y lo mismo re / zando un Credo". Aunque la fecha se refiera a la bendición, creemos que debió de hacerse antes de regalarlo a la persona correspondiente y por lo tanto de forma contemporánea a su hechura. Presenta evidencias de haber estado enmarcado, como corresponde a un cuadro de ofrenda. Ingresó en el museo por compra el 23/11/2007.

${ }^{33}$ En las facturas de José Losada de ese año, precisamente se conserva un único recibo por el pago de un "Santiago grande en cuadro" por el que se le pagaron 1.520 reales (940 de hechura y el resto de material). ACS. Cuentas, 1860-1867 (IG 580), recibo 11.

${ }^{34}$ ACS. Cuentas de Fábrica I (CB 465), separata de 1903-1904, recibo 210. Aparece reseñado en prensa en El Eco de Santiago, 30 de junio de 1904: 2; 23 de julio de 1904: 2; 25 de julio de 1904: 4; Gaceta de Galicia, 30 de julio de 1904: 3; El norte de Galicia, 2 de julio de 1904: 1; y La Correspondencia Gallega, 2 de julio de 1904: 2.

${ }^{35}$ ACS. Comprobantes de cuentas, (CB 200), separata de 1908-1909, sin f. Aparece reseñado en prensa en El Eco de Santiago, 27 de noviembre de 1909: 1. 
analizar estas dos obras en paradero ignorado. Estos dos ejemplos no nos sirven para comparar con ninguno los dos cuadros que le hemos atribuido con dudas, ya que en ambos casos toman una iconografía nueva. El primero reproduce el icónico Santiago peregrino románico del altar mayor, mientras que el segundo [figura 4], íntegramente sobredorado, sí toma la batalla de Clavijo pero bajo el modelo iconográfico desarrollado por José Ferreiro para el tímpano del Pazo de Raxoi (1774) ${ }^{36}$, tan repetido en su carrera, y que debió adoptar como propio varios años después, ejemplificándose en varios platos y bandejas. No sería difícil explicar, por lo tanto, que emplease el modelo de Clavijo convencional en esos dos primeros cuadros —el del doctor Sánchez Freire y el del Museo das Peregrinacións - , tempranos, y luego adoptase el modelo de Ferreiro - el de Alfonso XIII-.

Además de estos cuadros de carácter civil encargados por la Catedral, Martínez realizó un gran número de obras conmemorativas que se relacionan con momentos y personajes importantes de la ciudad, pedidos por las instituciones más representativas de la Compostela de su época. El hallazgo afortunado en su archivo de más de veinte fotografías de obras de este tipo, constatan que fue una de sus tipologías más pedida y, sin lugar a dudas, la más original y variada en sentido estilístico. Gracias a nuestro trabajo en la Hemeroteca de la Universidade de Santiago de Compostela vaciando los principales periódicos compostelanos de la época, hemos sido capaces de hallar un buen número de referencias alusivas a estos actos protocolarios e identificar a sus destinatarios.

A pesar de que no podemos mencionar en este caso todos los ejemplos, debemos detenernos en aquéllos más sobresalientes. Quizás el más espectacular sea la magnífica cornucopia que la Diputación de A Coruña encargó al platero en 1903 para regalar al exministro de Justicia Eduardo Dato (1856-1921) [figura 5] ${ }^{37}$. Periódicos no sólo gallegos sino de ámbito naciona ${ }^{38}$ reseñaron esta pieza por tratarse de una rareza tipológica, y bien es cierto que conocemos un número mínimo de ejemplos en toda Europa. Consiste en un gran marco decorativo, que ciñe espejos o escenas iconográficas, del que parten dos brazos con candelero en el que encajan las velas. Creemos que el platero conocía este tipo gracias a la magnífica pareja de cornucopias augsburguesas que envió la reina madre Mariana de Austria como ofrenda al apóstol Santiago en $1683^{39}$. Sabemos que Martínez intervino en estas piezas arreglándolas por lo menos en una ocasión, por lo que tuvo pleno conocimiento de su estructura ${ }^{40}$. Hasta la fecha, no conocemos otras obras similares en España $^{41}$. Martínez adaptó el tipo, nada habitual, aunque la disposición ovalada se hizo

\footnotetext{
${ }^{36}$ Sobre esta obra, véanse López Vázquez (1993: 90-100) y Otero Túñez (2004: 215-216).

${ }^{37}$ Fue abogado y político del Partido Conservador, ministro de Gobernación (1899-1900) y Gracia y Justicia (1902) de Francisco Silvela, y presidente del Gobierno (1913-1914 y 1920), en cuyo segundo mandato también ostentó la cartera de Marina (1920). En 1921 fue asesinado en un atentado contra su vida en Madrid.

${ }^{38}$ El Eco de Santiago, 6 de octubre de 1903: 2; La Época, 14 de octubre de 1903: 3; El Áncora, 9 de octubre de 1903: 3; Gaceta de Galicia, 9 de octubre de 1913: 3; y El Regional, 11 de octubre de 1913: 2.

39 Estas suntuosas piezas son obra de los padre e hijo homónimos Jakob Jäger, que realizaron los dos grandes relieves ovalados centrales; y Lukas Lang, que se encargó de las exuberantes coronas vegetales de hojas y flores de las que sobresalen los candeleros. Sobre estas piezas, véanse Cruz Valdovinos (1997: 329) y Pérez Varela (2016: 433-453).

${ }^{40}$ Las facturas se refieren a una "limpieza y arreglo de cornucopias", trabajo por el que se le pagaron 17 pesetas. ACS. Comprobantes de cuentas de Fábrica (IG 1017), separata de 1897, platero, sin f.

${ }^{41}$ En la Residencia de Múnich se conserva un juego de ocho cornucopias marcadas por Philipp Jakob IV Drentwett, hacia 1690-1695. Éstas tienen un tamaño algo mayor que las de la catedral de Santiago, y una
} 
verticalmente en lugar de horizontalmente, y en vez de los relieves veterotestamentarios de los Jäger, dispuso un espejo. Como detalle original del platero respecto al modelo augsburgués, culminó el caprichoso marco con un remate de una bicha alada sosteniendo la guirnalda con el escudo y las iniciales del homenajeado. Además, incorporó dos candeleros a distintas alturas, subrayando la asimetría que está impresa en toda la pieza. Mientras que las cornucopias augsburguesas resultan más naturalistas y barrocas, el marco de Martínez pertenece al pleno estilo rococó. Desgraciadamente desconocemos qué fue de la obra, una de las más suntuosas de todo el catálogo del platero.

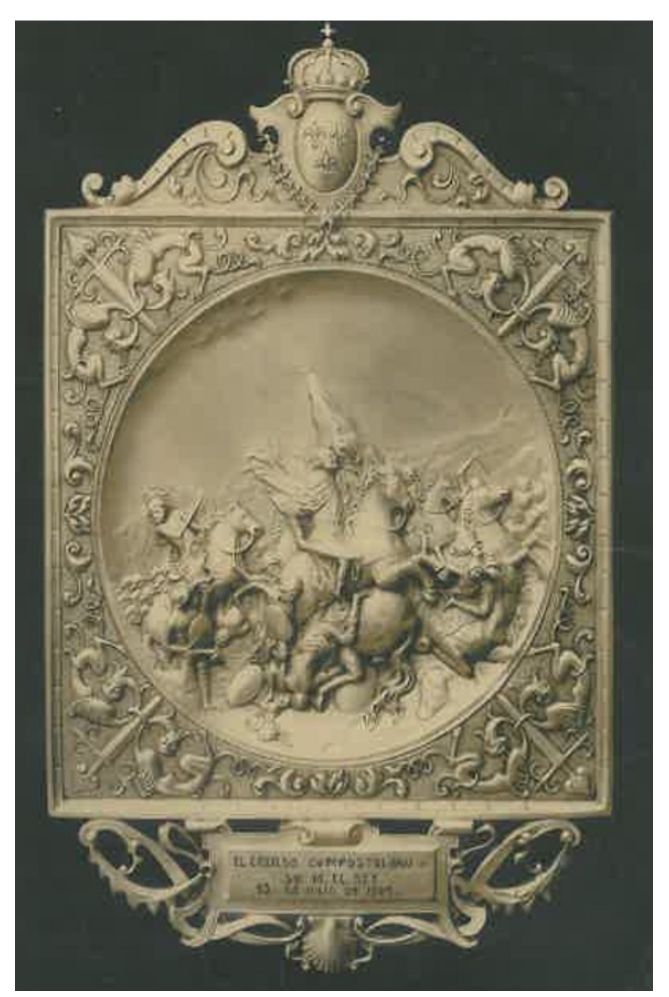

FIGURA 4: RICARDO MARTÍNEZ. CUADRO DE OFRENDA. 1909. PARADERO IGNORADO

Igual de espectacular resulta una pieza que Martínez realizó en 1910 para entregar nada menos que a Eugenio Montero Ríos (1832-1914) ${ }^{42}$, descrito en prensa como un

forma parecida, con los dos candeleros sobresalientes. Sin embargo, el trabajo decorativo no es tan rico, ya que carecen de relieve en el óvalo central y el marco vegetal está mucho más reducido (Cruz Valdovinos, 1997: 334). La imagen de las cornucopias de Múnich fue publicada en Seling (1980: tomo II, pieza 494).

${ }^{42}$ Fue catedrático de derecho canónico en las universidades de Oviedo (1859), Santiago (1860) y Madrid (1864); diputado en Cortes (1869); y ministro de Gracia y Justicia de Juan Prim (1870-1871) y Amadeo I (1871-1873). En 1873 participó en la fundación del Partido Republicano Democrático de Cristino Martos y en 1877 en la creación de la Institución Libre de Enseñanza, de la que fue rector hasta 1878. En 1884 se incorporó al Partido Liberal de Mateo Sagasta, con quien fue ministro de Fomento (1885), y de Gracia y Justicia (1892). Fue presidente del Tribunal Supremo (1888) y de la delegación española para el Tratado de París (1898). Sucedió en el Partido Liberal a Sagasta (1903), representando la facción más izquierdista, y finalmente fue nombrado presidente del gobierno de junio a diciembre de 1905. Para ampliar, véase Barral 
"artístico marco de plata repujado" de cincuenta centímetros ${ }^{43}$, que incorpora la dedicatoria en la parte inferior. La obra, sólo conocida por fotografía de su archivo, incorpora un tipo muy repetido en su catálogo que consiste en un plato redondo con la batalla de Clavijo, que toma la iconografía que ya hemos mencionado como derivada del modelo de José Ferreiro, y que Martínez había empleado un año antes para el cuadro de ofrenda de Alfonso XIII. El plato, que sigue una pauta propia del platero, con ancha orilla decorada con greca modernista, está abrazado por un enorme marco rococó que subraya el eclecticismo de la pieza. Orejas y ces en curva y contracurva, formas vegetales rizadas y escaroladas, y las habituales construcciones aveneradas de Martínez se combinan para crear una espectacular obra de ostentación.

Otra de estas piezas se refiere a una obra conjunta de Martínez con el escultor Ángel Bar, el pintor Urbano González y el herrero José Vilas, llevada a cabo en los talleres de nuestro platero en 1899. Consiste en un gran tablero de nogal al que se superpone una pantalla arquitectónica de plata, donde se encajan un medallón con busto y un lienzo al óleo de Urbano González, que "dando una nueva prueba de su inagotable inspiración, ha representado con verdad de efecto de espacio y de perspectiva un puente de nuestras pintorescas rías". Según el periódico, "todo el trabajo de orfebrería, excepción hecha de las figuras [modeladas por Ángel Bar], consta de tres planchas, dato que acusa las dificultades con que tropezó el artista para el movido de las ménsulas y cornisas y para conservar las superficies planas". Pese a que la identidad del retratado en busto no se menciona, la placa tiene una inscripción: Antonio Molina Galindo. El periódico también apuntó: "[Ricardo Martínez] ofrecerá una vez más ocasión de que en la corte de España se aprecie el justo renombre de que gozan los artistas compostelanos" 44 .

En 1908 se le encargó la obra para el homenaje que la Liga de Amigos le profesó al señor José Rodríguez Carracido (1856-1928), catedrático de bioquímica ${ }^{45}$, resuelto a modo de pantalla rectangular flanqueada por dos columnas arboladas y decorada con una alegoría de la Sabiduría, superpuesta a la fachada de la Universidad. En el mismo año realizó dos obras entregadas a Augusto González Besada (1865-1919) ${ }^{46}$, consistentes en dos grandes marcos para sendos diplomas que le otorgaron el ayuntamiento de Cambados y la Diputación de Pontevedra, con el fin de nombrarlo hijo adoptivo. La prensa menciona el de Cambados ${ }^{47}$ como un "marco estilo Luis XVI", con el escudo consistorial y dos vistas del puerto de Cambados antes y después de las obras patrocinadas por Besada, dos dibujos del artista pontevedrés Sanmartín. En cuanto al regalo correspondiente de la Diputación de Pontevedra ${ }^{48}$, consiste en un elegante marco de plata de clara inspiración

Martínez (2005).

${ }^{43}$ Diario de Galicia, 27 de septiembre de 1910: 2.

${ }^{44}$ El Eco de Santiago, 27 de mayo de 1899: 2-3. El artículo está firmado por Máximo de la Riva, industrial y político compostelano que sería elegido alcalde en 1922.

${ }_{45}$ José Rodríguez Carracido fue un bioquímico y farmacéutico compostelano, pionero de la bioquímica en España y primer catedrático del país en su disciplina. Fue rector de la Universidad Central de Madrid, hoy Universidad Complutense. Según la prensa (El Eco de Santiago, 26 de julio de 1908: 2) el 26 de julio de 1908, José Carracido llegó a Santiago para presidir el certamen que la Liga de Amigos tenía costumbre de celebrar anualmente en las fiestas del Apóstol.

${ }^{46}$ Augusto González Besada fue un político santiagués que ostentó los cargos de ministro de Hacienda, de Gobernación, y de Fomento, durante el reinado de Alfonso XIII.

${ }^{47}$ El Diario de Pontevedra, 14 de noviembre de 1908: 1.

${ }^{48}$ No hemos hallado noticias en prensa relativas al evento, pero la fotografía de la misma nos permite leer 
modernista. Cuando la ciudad de Santiago hizo el mismo nombramiento de hijo adoptivo al ministro dos años después, se encargó el diploma al calígrafo Antonio Rivera y el marco de plata al obrador de la viuda de Bacariza ${ }^{49}$.

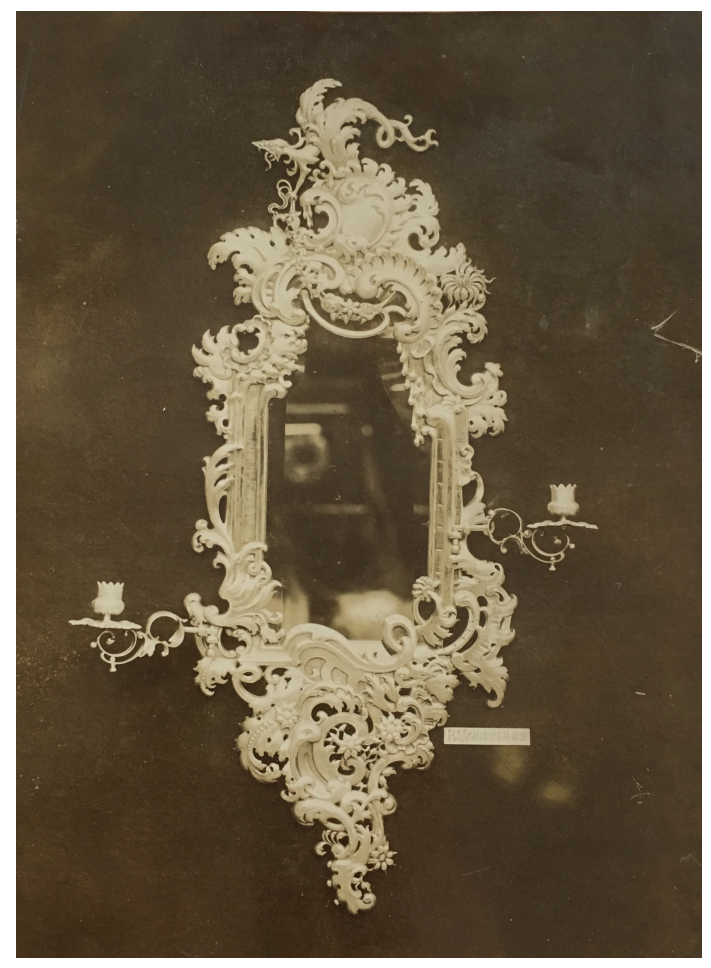

FIGURA 5: RICARDO MARTÍNEZ. CORNUCOPIA. 1904. PARADERO IGNORADO.

Por último, sin fecha conocida, tenemos una serie de placas fotografiadas halladas en su archivo que debieron responder a la función de regalos conmemorativos. Una de ellas fue entregada al arcipreste de la catedral de Santiago, Ramón de Valenzuela Carvajales por parte de sus "amigos y conterráneos del distrito de Silleda". Asimismo contamos con una serie de platos con el asiento decorado, que siguen el tipo del entregado a Montero Ríos y que por lo tanto pudieron usarse para lo mismo. Presentan variadas iconografías, entre las que destacan la batalla de Clavijo, una vista de la Catedral, o la fachada del sanatorio de Conxo. También entregada como regalo, realizó una bandeja para Guillermo II encargada en 1904 por un diplomático de la embajada de España en Alemania, pieza en la que al parecer le fue entregado al emperador el uniforme de coronel honorario del ejército español ${ }^{50}$.

el contenido de la carta, alusiva al nombramiento

49 Archivo do Museo do Pobo Galego (en adelante AMPG). Colección Blanco-Cicerón. Boletín de la Exposición Regional de 1909. Cuenta General de Ingresos y Gastos. Años de 1908, 1909, 1910 y 1911: 45.

${ }^{50}$ El Eco de Santiago, 29 de septiembre de 1927: 2; y 26 de octubre de 1904: 2. 
Asimismo encontramos dos obras conmemorativas en forma de libros. Una se corresponde con un obsequio a Cleto Troncoso Pequeño (1849-1922), destacado político compostelano, al ser nombrado rector de la Universidade de Santiago en $1906^{51}$. La plancha, que a primera vista podía parecer un cuadro conmemorativo, fue realmente empleada para adornar la portada de un álbum fotográfico. Fue descrita en prensa como una pieza elegante y modernista ${ }^{52}$, y en ella podemos ver, apenas incisa, de la fachada de la Universidad, hoy facultad de Geografía e Historia. Esta obra también fue expuesta en la vitrina del platero en la Exposición Regional de 1909, como podemos apreciar en la fotografía conservada. La otra obra no es una cubierta íntegra de un libro, sino solamente los esquinales y el gran escudo central, con el Toisón de Oro pendiendo. Hemos identificado esta obra como la referida en prensa para regalar a Alfonso XIII en 1909. Se trata de un libro realizado por el encuadernador pontevedrés Micó, para contener el expediente de posesión de la isla de Cortegada, que fue donada al monarca por los vecinos para construir una residencia de verano que nunca llegó a materializarse ${ }^{53}$.

Por último, contamos con la fotografía de una obra que por su morfología parece ser un guardacartas, compuesto por dos placas unidas por una base con patas. El frente ostenta una vista de la fachada del Seminario Mayor, antiguo monasterio de San Martiño Pinario, ceñido por grutescos. La estructura trasera, de estilo art decó, se compone a modo de dos esbeltos tallos retorcidos rematados en flor campaniforme. Se trata de una inusual pieza de orfebrería civil de la cual no hemos hallado más ejemplares. Gracias a la inscripción de la pieza sabemos que fue encargada por el Seminario para, de nuevo, Eugenio Montero Ríos, esta vez en fecha desconocida.

Para finalizar este apartado debemos mencionar una serie de placas y regalos diplomáticos de las cuales hemos tenido noticias gracias a la prensa, pero que no conocemos por fotografía: la cubierta de un álbum que los fieles regalaron al papa León XIII (1887) ${ }^{54}$; una placa con efigie del Apóstol regalada por Sánchez Miramontes al general Azcárraga (1903) $)^{55}$; otra que el tribunal eclesiástico de Mondoñedo encargó para su obispo (1906) ${ }^{56}$; la que entregó al presidente de la Cámara de Comercio de Pontevedra al ministro de Fomento $(1908)^{57}$; un premio de un certamen poético para el poeta Juan García San Millán (1910); el marco del pergamino entregado a don Máximo de la Riva en el homenaje que le brindó la ciudad (1913); la placa conmemorativa que entregaron los asistentes al VI Congreso Católico al ayuntamiento de Santiago (1916) ${ }^{58}$; la cubierta de un álbum para obsequiar a monseñor Ragonsesi, nuncio del Papa (1916) ${ }^{59}$; o un tercer álbum de fotografías de Luis Ksado con el que se agasajó a la infanta Isabel de Borbón,

\footnotetext{
${ }^{51}$ Doctor en derecho por la Universidade de Santiago de Compostela, obtuvo la cátedra de derecho romano en la Universidad de Oviedo, permutando posteriormente por la compostelana. Fue alcalde de Santiago entre 1891 y 1895, presidente de la Real Sociedad Económica de Amigos del País entre 1899 y 1906, y rector de la Universidad entre 1906 y 1919. En 1910 fue elegido senador por la provincia de Pontevedra.

${ }^{52}$ El Eco de Santiago, 5 de noviembre de 1906: 1.

${ }^{53}$ Gaceta de Galicia, 4 de junio de 1909: 1.

${ }^{54}$ Crónica de Pontevedra, 15 de junio de 1887: 3; y Gaceta de Galicia, 13 de junio de 1887: 3.

${ }^{55}$ El Eco de Santiago, 14 de septiembre de 1903: 2.

${ }^{56}$ El Eco de Santiago, 28 de marzo de 1906: 2; El Regional, 30 de marzo de 1906: 3; y La Correspondencia Gallega, 2 de abril de 1906: 2.

57 El Eco de Santiago, 19 de junio de 1908: 2. Por cronología, creemos que se trata del ministro José Sánchez-Guerra Martínez.

${ }^{58}$ Boletín Oficial del Arzobispado de Santiago, 20 de mayo de 1916: 532-533.

${ }^{59}$ El Progreso, 5 de enero de 1916: 3.
} 
hermana de Alfonso XII, en su visita a Compostela $(1917)^{60}$. Con todos estos ejemplos, y contando con los cuadros entregados a Alfonso XIII y a Sánchez Freire por la Catedral, y las obras de Martín de Herrera, hemos hecho acopio de más de una treintena de obras conmemorativas que certifican la variedad de clientela y encargos de este tipo que recibió.

\section{ARTE, INDUSTRIA Y PROGRESO: EL CENICERO DE LA EXPOSICIÓN REGIONAL DE 1909}

La última pieza que queremos destacar en este estudio es una obra hallada entre las pertenencias del propio Ricardo Martínez, guardadas por su familia. Se trata de un curioso cenicero [figura 6] que ya a simple vista llama la atención por su aspecto. Tiene un enorme interés desde un punto de vista estilístico, ya que introduce una influencia modernista de raíz catalana de gran originalidad en Compostela, que el platero hubo de conocer gracias a su viaje a Barcelona en 1892 para acudir a la exposición de Industrias Artísticas, donde fue premiado con una medalla (Pérez Varela, 2019: 312). Y a pesar de ese interés morfológico, el mayor valor de la pieza es su importancia simbólica y su uso.

La pieza reproduce una vista del pabellón central de la gran Exposición Regional de Santiago de 1909, sobre la leyenda: "SANTIAGO / R. MARTINEZ / RECUERDO DE LA EXPOSICIÓN". Hemos hallado varias referencias a esta pieza en la prensa de la época. En 1913, el platero donó "un par de ceniceros de metal blanco repujados con vistas del Pabellón Central de la Exposición" para contribuir en la kermesse que se organizó para sufragar el monumento a Rosalía de Castro ${ }^{61}$. El hecho de que donase dos, cuatro años después del evento, y él se quedase por lo menos con uno, nos indica que debió de hacer varios ejemplares para regalar, tal y como reza su inscripción, como "recuerdo". La técnica empleada para su construcción fue evidentemente el moldeado, a pesar de la información errónea que reproduce el periódico al referirse a él como "repujado", palabra que en la época se usaba habitualmente para definir cualquier trabajo de plata con un dibujo en relieve. El material es metal plateado a la manera tradicional.

Esta obra conecta con una realidad de enorme interés radicada precisamente en el contexto histórico en el que nos estamos moviendo, como es la de la celebración de exposiciones regionales y de artes y oficios, que fueron promovidas en toda Europa por distintas instituciones culturales y económicas. En el caso de Compostela, es de obligada mención la Real Sociedad Económica de Amigos del País de Santiago ${ }^{62}$. Ésta fue fundada en 1784 por un grupo de compostelanos encabezados por Antonio Páramo y Somoza (1731-1786) como organismo que velara e impulsara los intereses económicos y culturales del territorio de Galicia, a imagen y semejanza de las que habían tomado forma en algunos lugares del país. Desde un punto de vista calificado por Singul Lorenzo (2001: 67) como "filantrópico, patriótico y un tanto paternalista", la Sociedad fue uno de los mayores agentes de dinamización cultural del siglo XIX. Siguió de forma general las pautas marcadas por la pionera Sociedad Bascongada y que el gobierno institucionalizó

${ }^{60}$ Diario de Galicia, 17 de mayo de 1917: 1; y El Ideal Gallego, 19 de abril de 1922: 8.

${ }^{61}$ El Correo de Galicia, 14 de julio de 1913: 2; El Eco de Santiago, 14 de julio de 1913: 2; y Diario de Galicia, 16 de julio de 1913: 1.

62 Sobre esta institución son imprescindibles los estudios de Fernández Casanova (1981), Fraguas Fraguas (1986) y Fernández Castiñeiras y Folgar de la Calle (eds.) (2006). 
en la Matritense a fin de crear un modelo pautado. Promovió considerablemente el desarrollo de la agricultura, la ganadería, la industria y el comercio; introdujo técnicas modernas de producción y cultivo; renovó y abrió redes viarias, y fomentó la repoblación forestal. Además, impulsó extraordinariamente las Letras y las Artes a través de la creación de premios, un museo arqueológico, diversas publicaciones especializadas, y varias escuelas dedicadas a la enseñanza de Artes y Oficios. Estos talleres de raíz académica e ilustrada canalizaron en gran medida la enseñanza de los oficios en Santiago, y vinieron a intentar sustituir, como ya lo estaban haciendo en el resto del mundo, al sistema gremial de aprendizaje de obradores heredado de la Edad Media.

Una de las más interesantes contribuciones a la promoción de los oficios artísticos y gremiales de Compostela llevadas a cabo por la Sociedad Económica fue precisamente la de la impulsar la celebración de exposiciones regionales. Su puesta en escena corrió en paralelo al auge que estaban teniendo los eventos de este tipo en todo el mundo a lo largo del siglo XIX ${ }^{63}$, debido en gran medida, a la necesidad de mostrar los continuos avances en una sociedad dominada por el progreso como nunca antes, y de hacer partícipes y aclimatar a los propios espectadores a la nueva realidad industrial en constante avance. En acertadas palabras de Fernández Casanova (1982: 108):

"Dentro del espíritu de transformación de la centuria pasada, manifiesto de la eclosión del movimiento científico y sus repercusiones en el desarrollo material e ideológico, las exposiciones de cualquier carácter cumplen, de forma general, la finalidad de muestra y exhibición de las innovaciones alcanzadas. Al elevado número de exposiciones celebradas a lo largo del siglo XIX, en sus vertientes internacional, nacional, regional y provincial, se les puede aplicar el comentario que mereció la Gran Exposición Universal de Londres, de 1851, valorada como medio de apresar el vuelo viviente del progreso humano, marcado con cada conquista de la inteligencia del hombre".

Estos eventos no sólo supusieron un escaparate riquísimo de intercambio de influencias, sino que, como apuntaron Sousa y Pereira (1988: 7), motivaron reflexiones teóricas muy interesantes, como las del De l'Union de l'Art e l'Industrie de León de Laborde; The True and the False in the Decorative Arts de Owen Jones; o los textos de Gotfried Semper y William Morris. En estas obras se deliberó acerca de la importancia de la conjunción armónica entre arte e industria, la sistematización del aprendizaje en los artesanos, y la formación de los mismos en el gusto estético. Además, la mejora de las técnicas y los recursos propuestos por Morris defendieron la perpetuación del trabajo artesanal de calidad sin sucumbir a la fría mecanización en cadena, y conservando el aura artística de los productos ${ }^{64}$.

Además de evidenciar esta relación entre arte e industria ${ }^{65}$, estos grandes eventos supusieron un escaparate en el que las diferentes regiones expusieron los avances de sus

${ }^{63}$ Las muestras pioneras fueron las del siglo XVIII en Londres (1757) y Praga (1791). La primera decimonónica se celebró en París en 1819, mientras que en el ámbito nacional, fue en Madrid en 1827. Sin embargo éstas no alcanzarían la dimensión y sentido de las grandes exhibiciones de la segunda mitad del siglo XIX (Requejo Alonso, 2006: 148). La primera considerada con la categoría de "universal" sería la de Londres en 1851 y daría el pistoletazo de salida a una sucesión de exposiciones en las distintas capitales europeas que quisieron emular la magnitud de la exhibición inglesa (Canogar, 1992: 23).

${ }^{64}$ Sobre William Morris, véase Le Mire (2006),

${ }^{65}$ Díaz de Rábago y Ramón Núñez Fernández, profesores de la Escuela de Artes Oficios de Santiago, habían insistido a través de sus discursos, escritos, y magisterio, en la importancia de esta relación recíproca e indisoluble (Durán Rodríguez, 2012: 156). 
ingenieros, artistas, artesanos y trabajadores, en una constante búsqueda de mostrar el progreso como meta más valiosa en una sociedad ilustrada cada vez más mercantilizada e industrializada. Pero no sólo eso, sino que, por primera vez, y ya hacia finales del siglo XIX, estas exhibiciones sirvieron para identificar el arte como un componente fundamental de la definición de la cultura y la imagen de un país, en nuestro caso, de Galicia (López Vázquez, 1998: 15-25).

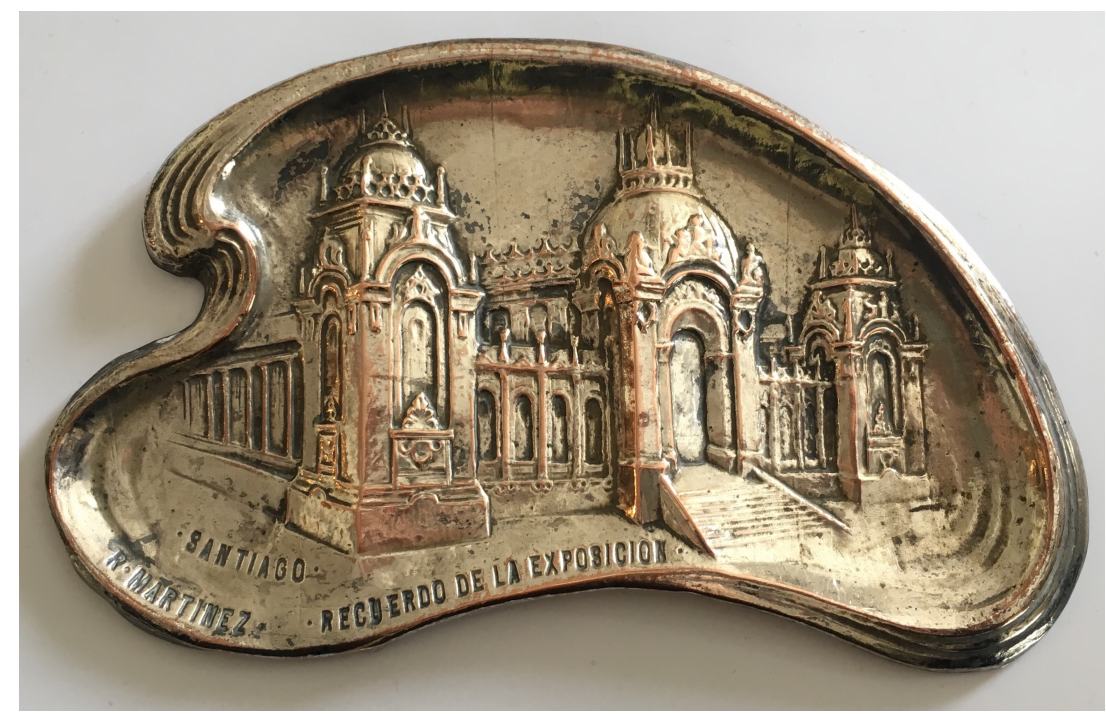

FIGURA. 6: RICARDO MARTÍNEZ. CENICERO. 1909. COLECCIÓN PARTICULAR.

Con respecto a la valoración de los objetos expuestos, en las exposiciones españolas fue inevitable que las llamadas artes industriales jugasen un papel menor, teniendo en cuenta el contexto decimonónico de separación entre artes mayores y menores. Por un lado, se alzaron voces defendiendo su equiparación e incluso relacionando directamente el progreso con las artes industriales como propias, como su etimología refiere, de la industria. Esta revalorización corrió paralela a la importancia que estaban alcanzando estas artes en Europa, y que las llevó a ser, por ejemplo, el gran atractivo de la Exposición Universal de París de 1900. Sólo Cataluña, región más preocupada por lo que sucedía en Inglaterra, Alemania y Francia, y con una estructura de artes industriales de gran calidad basadas en el modernismo, organizó sucesivas exposiciones específicas apoyadas por el gobierno municipal. A partir de 1897 estas artes ya se consideraron parte de las Exposiciones Nacionales. Por otra banda, algunos personajes conservadores se quejaron por esta equiparación ya que según su criterio no deberían estar a la misma altura que las Bellas Artes. Sorprendentemente, éste fue el caso de Balsa de la Vega (Gutiérrez Burón, 1986: 22), historiador paradójicamente muy preocupado por la orfebrería gallega en sus estudios

En Santiago, la Sociedad Económica fue la responsable del impulso de las exposiciones regionales de 1858, 1875, 1885, 1897, y especialmente, la gran muestra de 
1909. La naturaleza de meta de peregrinación, inherente a Compostela, llevó a los promotores de las mismas a hacerlas coincidir con los Años Santos, de gran afluencia turística y de visitantes (Requejo Alonso, 2006: 150). Su calado en la sociedad compostelana se difundió especialmente a través de publicaciones periódicas como la Revista de la Sociedad Económica de Amigos del País de Santiago, publicada entre 1882 y 1890; o Galicia. Revista universal de este reino, que nació en el año 1887 (Barral Martínez, 2010: 86).

La Exposición Regional de 1909 se encajó dentro de un año de fervorosa actividad cultural en Santiago. No sólo coincidió con la celebración del Año Santo, sino también con la IV Semana Social, el primer Congreso Franciscano o importantes peregrinaciones como la de los católicos ingleses presidida por el arzobispo londinense de Westminster. Además, la propia comisión organizadora programó actividades paralelas multitudinarias, como el Congreso de Primera Enseñanza, el de Emigración, el de Ciencias Médicas, certámenes pirotécnicos, conciertos y conferencias (Fandiño Veiga, 2010: 251-265).

La exposición de 1909 destacó, con respecto a sus antecesoras y aquéllas llevadas a cabo en otras ciudades gallegas, por la extensión del espacio expositivo, la variedad y singularidad de los objetos escogidos, y la arquitectura efímera de sus pabellones. En los terrenos que ocupan hoy día la Alameda y el Campus Sur de la Universidad, se levantó un ambicioso proyecto de arquitectura efímera, del que en la actualidad sólo se conserva el pabellón de Recreo Artístico e Industrial, obra de Antonio Palacios ${ }^{66}$. El pabellón de Industrias, en donde se expusieron las obras de los plateros compostelanos contemporáneos, se situaba en tres edificios que rodeaban en semicírculo la cara trasera del pabellón central, con una superficie que, según Carro García (1959: 11), no fue lo suficientemente amplia para albergar las 567 exposiciones que se organizaron. El rey Alfonso XIII y el presidente del Consejo de Ministros, Antonio Maura, acudieron a inaugurar la muestra y a profesarle grandes halagos (Rodríguez González, 1999: 30).

Uno de los grandes aciertos de la Exposición fue la conjunción efectiva de la industria y el arte. La Escuela de Artes y Oficios de Santiago, en cuyo discurso de inauguración Díaz de Rábago ya había dejado clara la importancia de las exposiciones, tuvo pabellón propio, así como la escuela homónima viguesa. La compostelana además jugó un papel importante en su organización, tanto sus profesores: Ramón Núñez, Enrique Mayer, José María Fenollera, Rafael de la Torre, Álvaro Caula o Manuel Álvarez Reyero; como exalumnos de la Escuela: los fotógrafos Enrique Sánchez Guerra y Manuel Chicharro Bisí, que documentaron la muestra. La Escuela ganó un diploma de honor y algunos alumnos y profesores obtuvieron medallas individuales (Sousa y Pereira, 1988: 75-76, y Durán Rodríguez, 2012: 154). Asimismo, sabemos que además de Ricardo Martínez, fueron premiados los plateros compostelanos Andrés Lado, Eduardo Rey y la viuda de Bacariza, María Varela (Carro García, 1959: 12).

Además de la obra contemporánea expuesta en el pabellón de industria, los visitantes y los propios plateros compostelanos tuvieron la oportunidad de ver un compendio de la mejor platería gallega en la Sección Arqueológica de la exposición,

\footnotetext{
${ }^{66}$ El diseño de los edificios se debió a los arquitectos vigueses Antonio Flórez Urdapilleta y Manuel Gómez Román. Sobre la arquitectura de la exposición, véase Vigo Trasancos (2010: 74-76).
} 
emplazada en el Colegio de San Clemente (Fariña Busto, 2010: 195-200). Ésta es una exposición especialmente significativa para nuestra investigación, ya que Ricardo Martínez actuó como vocal en la comisión organizadora de dicha Sección. Ésta se encargó de exponer "en toda su variedad y extensión los documentos artísticos, ya folclóricos de Galicia, anteriores al siglo XIX" que ofreciesen "algún interés para el conocimiento de nuestra región en sus orígenes étnicos, en sus costumbres características y en su desenvolvimiento histórico" ${ }^{16}$. Martínez formó parte de las numerosas reuniones de la organización y de actos importantes como el viaje a Pontevedra en el que conoció a Augusto González Besada, ministro de Fomento, y al ilustre santiagués Eugenio Montero Ríos, entre otras personalidades ${ }^{68}$. De hecho, como acabamos de ver en el epígrafe anterior, realizó obras conmemorativas para ambos personajes.

Además, el artífice debió de tener competencia en la selección y disposición de las obras de plata. Entre éstas, colocadas en el llamado "salón de honor", destacan las dos magníficas piezas augsburguesas donadas por Mariana de Neoburgo a la Colexiata de Santa María do Campo (A Coruña), perfectamente visibles en dos fotografías de dicho salón ${ }^{69}$. En la muestra también participó una exquisita colección de piezas medievales y modernas recogidas de todas las parroquias y centros conventuales gallegos, entre las que sobresalieron las joyas de la catedral de Santiago (Carro García 1959: 13-15).

Estamos por lo tanto ante un proyecto excepcional, fruto de la colaboración conjunta entre todas las instituciones y personalidades expuestas, pero también del tejido artesanal e industrial de la ciudad (Fernández González y Giráldez Rivero, 2010: 79). En palabras de Monterroso Montero (2004: 38), la muestra contribuyó enormemente a la renovación del arte gallego en las bellas artes, fruto de "la semilla plantada por el regionalismo [...]", que "legitimaría una labor que aspiraba a conciliar el pasado con el presente, las tendencias estéticas peninsulares y la identidad galaica". De este modo, Compostela quiso presentarse al público como una ciudad moderna, que despertaba del letargo en el que había estado sumida a lo largo del siglo XIX. La propia organización definió el experimento como "la apoteosis de nuestra raza, representada por las glorias de pasado, las energías del presente y las esperanzas del porvenir"70.

Como ya hemos mencionado, en el archivo del artista hemos hallado una fotografía que nosotros hemos identificado de forma inequívoca con la vitrina de obra que exhibió en la muestra [figura 7]. Acoge todo tipo de piezas, con el soberbio sagrario de la Enseñanza como pieza protagonista, rodeado de bandejas, espejos, y otras piezas reconocibles de su catálogo. Este documento gráfico nos permite saber más de su participación en estos eventos, y conocer la forma de exponer este tipo de obras, ya que los catálogos de la época raramente incluyen imágenes. Los documentos registran que su vitrina estaba emplazada en el Pabellón de Industria, creado para impulsar la visibilidad y calidad del arte y la artesanía de la región ${ }^{71}$, y por su trabajo se le premió con una

${ }^{67}$ AMPG. Reglamento General de la Exposición Regional Gallega que ha de celebrarse en la ciudad de Santiago en el Año Santo de 1909: 4.

${ }^{68}$ Boletín de la Exposición Regional de 1909, septiembre de 1908, núm. 2: 1-2.

${ }^{69}$ Sobre estas obras, véase Pérez Varela (2016).

${ }^{70}$ Así se nombró en el Boletín de la Exposición Regional, noviembre de 1908, núm. 3: 1.

${ }^{71}$ Boletín de la Exposición Regional de 1909, julio de 1908, núm. 1: 4. 
medalla de oro ${ }^{72}$ "por objetos de orfebrería"73, dentro de la "3a División, $6^{\text {a }}$ Clase $^{74}$ : Orfebrería, Joyería, Lapidario y Damasquinado"75, de la Sección Contemporánea.

\section{A MODO DE CONCLUSIÓN}

Vemos pues cómo estas obras escogidas, más allá de su interés formal y sus influencias estilísticas, transparentan una lectura mucho mayor que tiene que ver con su uso y simbolismo. La urna de Santiago refleja, a través de la elección de su estilo, la defensa de la cuestión jacobea y el uso del historicismo estético con una vocación histórica y política.

Los cuadros de ofrenda y las placas conmemorativas nos hablan de un contexto celebrativo en los tres pilares de poder fundamentales de la Compostela de la época: Catedral, Ayuntamiento y Universidad. Estas placas nos cuentan con sus inscripciones y alegorías la historia de la ciudad, los homenajes a sus personajes más ilustres o las visitas reales. Éstas últimas, celebradas con pompa y grandes fastos, se enmarcan en un ambiente de reactivación de las peregrinaciones y engrandecimiento del culto jacobeo tras la segunda inventio, cuando la ciudad supo aprovechar al Apóstol como valor universal que promover y celebrar.

Y finalmente, el pequeño cenicero que guardó el propio Ricardo Martínez nos habla del próspero contexto de las exposiciones regionales, cuando Compostela despertó a la necesidad finisecular de modernizarse. En este paradigma, la ciudad tuvo la necesidad de mostrar el avance y progreso de sus agricultores, industriales y artesanos. Éstos últimos, entre los que se encontraba el propio Ricardo, ya aparecen plenamente integrados en las instituciones culturales de la ciudad, participando, como en su caso, en la propia organización de la muestra.

En definitiva, nos encontramos ante una serie de obras a través de las cuales quedan ejemplificados tres de los elementos fundamentales de la historia de la Compostela del cambio del siglo XIX al XX: el Apóstol como emblema universal, el contexto celebrativo y la conjunción de arte, industria y progreso. Tres realidades

\footnotetext{
${ }^{72}$ Los premios otorgados en dicha exposición, por orden de importancia, fueron: Gran Premio, Diploma de honor, Medalla de oro, Medalla de plata, Medalla de bronce, Mención honorífica y Diploma de cooperación AMPG. Reglamento General de la Exposición Regional Gallega que ha de celebrarse en la ciudad de Santiago en el Año Santo de 1909: 13.

73 Archivo do Instituto de Estudos Galegos Padre Sarmiento (en adelante AIEGPS). Exposición Regional Galega. 1909. Caja núm. 6/15. Registro de los expositores que han sido premiados.

${ }^{74}$ Las divisiones eran las siguientes: $1^{\mathrm{a}}$ Bellas Artes; $2^{\mathrm{a}}$ Ciencias Aplicadas; $3^{\mathrm{a}}$ Industrias; y Grupos Especiales. En cuanto a las clases, los documentos son contradictorios. Mientras que algunos sitúan a la orfebrería dentro de la Clase $6^{\mathrm{a}}$ (AIEGPS. Exposición Regional Galega. 1909. Caja núm. 6/15. Documentación para los Sres. Jurados. Relación de los expositores que corresponderán a cada división y sección); y otros en la Clase 11 ${ }^{\mathrm{a}}$ (Boletín de la Exposición Regional de 1909, septiembre de 1908, núm. 2: 7); el Reglamento General de la Exposición la contempla en la Clase 18 ${ }^{\mathrm{a}}$ (AMPG. Reglamento General de la Exposición Regional Gallega que ha de celebrarse en la ciudad de Santiago en el Año Santo de 1909: 19).

75 AIEGPS. Exposición Regional Galega. 1909. Caja núm. 6/15. Documentación para los Sres. Jurados. Relación de los expositores que corresponderán a cada división y sección.
} 
plasmadas en piezas de platería compostelana, disciplina artística que creemos, todavía tiene muchos frutos que ofrecer en la configuración historiográfica de Santiago.

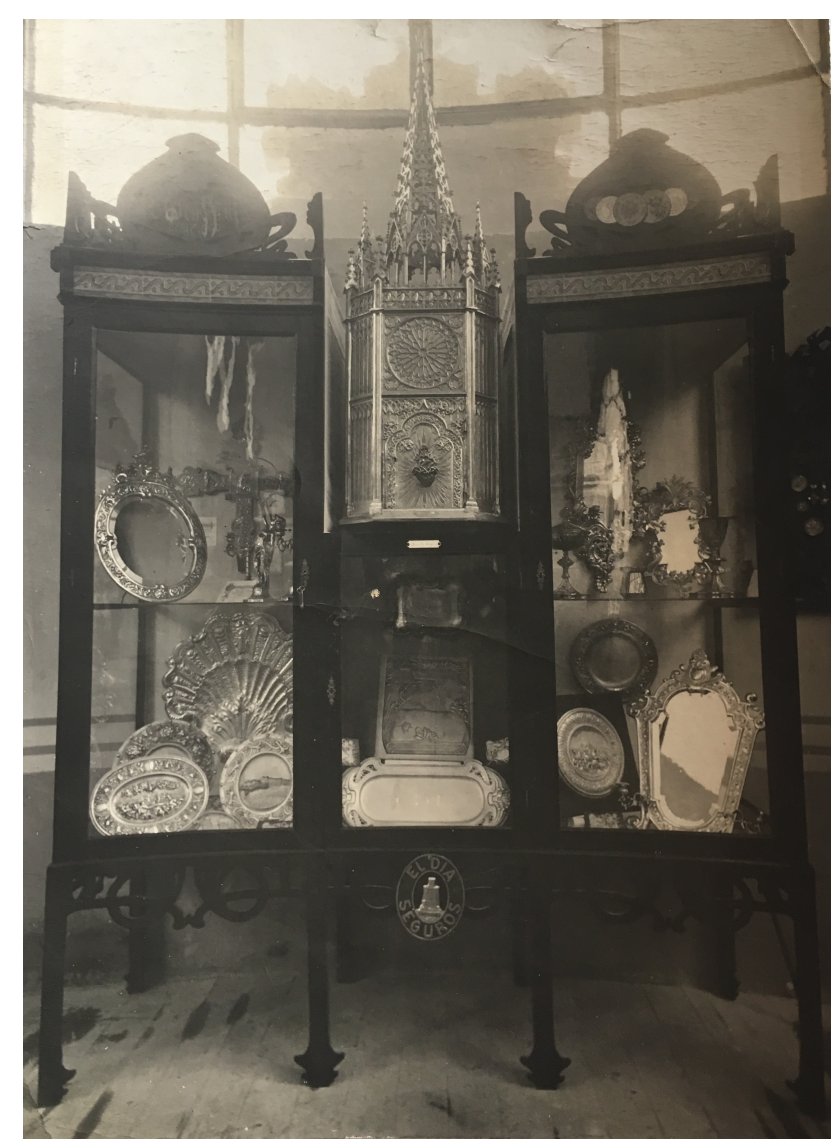

FIGURA. 7: RICARDO MARTÍNEZ. VITRINA. 1909. COLECCIÓN PARTICULAR.

\section{FUENTES DOCUMENTALES}

ACS. Actas Capitulares. Libro 79 (IG 634), cabildos del 31 de enero de 1879, ff. 214r-214v; y 1 de febrero de 1879, ff. 214v-215r; Libro 80 (IG 635), cabildos del 27 de octubre de 1885, ff. 92r93r; 28 de junio de 1886, ff. 111r-111v; 13 de febrero de 1891, ff. 276r-276v; y Acta de colocación de los restos apostólicos en la urna, ff. 117r-119v.

ACS. Cuentas, 1860-1867 (IG 580); y 1885 (IG 584).

ACS. Cuentas de Fábrica I (CB 465), separata de 1903-1904, recibo 210.

ACS. Comprobantes de cuentas, (CB 200), separata de 1908-1909, sin f.

ACS. Comprobantes de cuentas de Fábrica (IG 1017), separata de 1897, platero, sin f.

AIEGPS. Exposición Regional Galega. 1909. Caja núm. 6/15. Documentación para los Sres. Jurados. Relación de los expositores que corresponderán a cada división y sección; y Registro de los expositores que han sido premiados.

AIEGPS. Colección Blanco-Cicerón. Boletín de la Exposición Regional de 1909. Cuenta General de Ingresos y Gastos. Años de 1908, 1909, 1910 y 1911.

AMPG. Reglamento General de la Exposición Regional Gallega que ha de celebrarse en la ciudad de Santiago en el Año Santo de 1909. 


\section{FUENTES IMPRESAS}

Boletín de la Exposición Regional de 1909, julio de 1908; septiembre de 1908; y noviembre de 1908.

Boletín Oficial del Arzobispado de Santiago, 7 de agosto de 1884, 17; y 20 de mayo de 1916, $532-533$

Crónica de Pontevedra, 15 de junio de 1887, 3.

Diario de Galicia, 27 de septiembre de 1910, 2; 16 de julio de 1913, 1; y 17 de mayo de 1917, 1.

El Áncora, 9 de octubre de 1903, 3.

El Correo de Galicia, 14 de julio de 1913, 2

El diario de Pontevedra, 14 de noviembre de 1908, 1.

El Eco de Santiago, 27 de mayo de 1899, 2-3; 14 de septiembre de 1903, 2; 6 de octubre de 1903, 2; 30 de junio de 1904, 2; 23 de julio de 1904, 2; 25 de julio de 1904, 4; 26 de octubre de 1904, 2; 28 de marzo de 1906, 2; 5 de noviembre de 1906, 1; 19 de junio de 1908, 2; 26 de julio de 1908, 2; 27 de noviembre de 1909, 1; 14 de julio de 1913, 2; y 29 de septiembre de 1927.

El Ideal Gallego, 19 de abril de 1922, 8.

El norte de Galicia, 2 de julio de 1904, 1.

El Progreso, 5 de enero de 1916, 3.

El Regional, 30 de marzo de 1906, 3; y 11 de octubre de 1913, 2.

Gaceta de Galicia, 13 de junio de 1887, 3; 25 de julio de 1894, 2; 30 de julio de 1904, 3; 4 de junio de 1909, 1; y 9 de octubre de 1913, 3.

Galicia Diplomática, 9 de febrero de 1884, 219-220; y 20 de febrero de 1884, 235-236.

La Correspondencia Gallega, 2 de julio de 1904, 2; y 2 de abril de 1906, 2.

La Época, 14 de octubre de 1903, 3.

\section{BIBLIOGRAFÍA}

Barral Martínez, M. (2005). Eugenio Montero Ríos e a Cidade de Santiago. Santiago de Compostela: Universidade de Santiago de Compostela.

Barral Martínez, M. (2010). O espírito expositivo na época contemporánea e na organización e desenvolvemento da Exposición Regional Galega de 1909. En Exposición galega de 1909: conmemoración do $1^{o}$ centenario da Exposición Regional Gallega, Santiago 1909. Santiago de Compostela: Consorcio de Santiago, Museo do Pobo Galego e Instituto de Estudos Galegos Padre Sarmiento.

Borrow, G. (1996). La Biblia en España. Madrid: Alianza Editorial [edición original, Londres: John Murray, 1843].

Bouza Brey, F. (1962). Platería civil compostelana hasta finales del siglo XIX. Santiago de Compostela: Instituto de Estudos Galegos Padre Sarmiento.

Canogar, D. (1992). Ciudades efimeras. Exposiciones Universales: Espectáculo y Tecnología. Madrid: Julio Ollero Editor.

Carro García, J. (1954). Estudios jacobeos: ara marmórica, cripta, oratorio o confesión, sepulcro y cuerpo del Apóstol. Santiago de Compostela: Instituto de Estudos Galegos Padre Sarmiento.

Carro García, J. (1959). La Exposición Regional Gallega de 1909. Santiago de Compostela: Instituto de Estudios Galegos Padre Sarmiento.

Castellá Ferrer, M. (1610). Historia del Apóstol de Iesus Christo Sanctiago Zebedeo Patrón y Capitán General de las Españas. Madrid: Alonso Martínez de Balboa.

Castillo Oreja, M. A. (coord.) (2001). Las catedrales españolas en la Edad Moderna: aproximación a un nuevo concepto del espacio sagrado. Madrid: Fundación BBVA.

Cebrián Franco, J. J. (1998). Los siete Varones Apostólicos. Compostela, 16, 1998, 4-7.

Cruz Valdovinos, J. M. (1997). Platería europea en España (1300-1700). Madrid: Fundación Central Hispano-1997.

Duchesne, L. (1900). Saint Jacques en Galice. Annales du Midi, 12, 145-179.

Durán Rodríguez, M. D. (2012). Las Exposiciones Universales y Regionales como recurso didáctico en las Escuelas de Artes y Oficios (1886-1939). Sarmiento, 6, 143-165.

Elorduy, E. (1954). De re jacobea. Boletín de la Real Academia de la Historia. 135, 323-335. 
Fandiño Veiga, X. R. (2010). Actividades complementarias. En Exposición galega de 1909: conmemoración do $1^{\circ}$ centenario da Exposición Regional Gallega, Santiago 1909. Santiago de Compostela: Consorcio de Santiago, Museo do Pobo Galego e Instituto de Estudos Galegos Padre Sarmiento, 251-265.

Fariña Busto, F. (2010). Notas arredor da sección arqueolóxica. En Exposición galega de 1909: conmemoración do $1^{\circ}$ centenario da Exposición Regional Gallega, Santiago 1909. Santiago de Compostela: Consorcio de Santiago, Museo do Pobo Galego e Instituto de Estudos Galegos Padre Sarmiento, 195-206.

Fernández Casanova, C. (1981). La Sociedad Económica de Amigos del País de Santiago en el siglo XIX. Un estudio de la organización interna y de su actuación a favor de Galicia. Sada: Ediciós do Castro, Sada.

Fernández Casanova, C. (1982). La Exposición regional de Santiago en 1858. Revista de Historia Contemporánea, 1, 108-137.

Fernández Castiñeiras, E., y Folgar de la Calle, M. C. (eds.) (2006). Real Sociedade Económica de Amigos do País de Santiago de Compostela (1784-2006). Santiago de Compostela: Fundación Caixa Galicia.

Fernández González, A. I., y Giráldez Rivero, J. (2010). Santiago 1909: a economía galega no escaparate da Exposición Rexional, En Exposición galega de 1909: conmemoración do $1^{\circ}$ centenario da Exposición Regional Gallega, Santiago 1909. Santiago de Compostela: Consorcio de Santiago, Museo do Pobo Galego e Instituto de Estudos Galegos Padre Sarmiento, 79-119.

Fernández Sánchez, J. M. y Freire Barreiro, F. (1880). Santiago, Jerusalén, Roma: diario de una peregrinación a estos y otros santos lugares de España, Francia, Egipto, Palestina Siria e Italia en el año del jubileo universal de 1875. Santiago de Compostela: Imprenta del Boletín Eclesiástico.

Fita, F., y Fernández-Guerra, A. (1880). Recuerdos de un viaje a Santiago de Galicia. Madrid: Imprenta de los Sres. Lezcano y Compañía.

Fraguas Fraguas, A. (1986). Real Sociedad Económica de Amigos del País de Santiago. Primera Época: 1784-1813-1821. Santiago de Compostela: Real Sociedad Económica de Amigos del País de Santiago.

García de Villada, Z. (1928). Historia eclesiástica de España. Madrid: Compañía IberoAmericana de Publicaciones.

Garrido, G. A. (1994). Aventureiros e curiosos. Relatos de viaxeiros estranxeiros por Galicia, séculos $X V$-XX. Vigo: Galaxia, 303-304.

Guerra Campos, J., y Cebrián Franco, J. J. (ed.) (2003). Estudios y ocurrencias sobre la Cuestión de Santiago en el siglo XX. Revisión panorámica. Compostellanum, 48/1-4, 448-514.

Guerra Campos. J. (1982). Exploraciones arqueológicas en torno al sepulcro del Apóstol Santiago. Santiago de Compostela: Cabildo de la Catedral de Santiago de Compostela.

Gutiérrez Burón, J. (1986). Los enviados especiales a las exposiciones universales del siglo XIX. En Los Caminos y el Arte. Actas del VI Congreso Español de Historia del Arte. Santiago de Compostela: Universidade de Santiago de Compostela, 13-25.

Le Mire, E. D. (2006). A bibliography of William Morris. New Castle-Londres: Oak Knoll PressBritish Library.

López Ferreiro, A. (1877). El altar de Santiago, sus vicisitudes y transformaciones desde los tiempos primitivos hasta nuestros dias. Santiago de Compostela: Imprenta del Boletín Eclesiástico.

López Ferreiro, A. (1898-1909). Historia de la Santa Apostólica Metropolitana Iglesia de Santiago de Compostela, 11 vols. Santiago de Compostela: Seminario Conciliar Central.

López Ferreiro, A. (1981). Altar y cripta del apóstol Santiago. Reseña histórica desde su origen hasta nuestros días. Santiago de Compostela: Imprenta y Encuadernación del Seminario Conciliar Central.

López Vázquez, J. M. (1993). Neoclasicismo. En Galicia Arte. Tomo XV: Arte Contemporánea. A Coruña: Hércules. 28-133.

López Vázquez, J. M. (1998). Introducción. En Artistas Galegos. Pintores. Tomo II: Novecentos. 
Vigo: Nova Galicia Edicións, 15-25.

Mateo Sevilla, M. (1991): El Pórtico de la Gloria en la Inglaterra Victoriana: la invención de una obra maestra. Santiago de Compostela: Museo Nacional de las Peregrinaciones.

Mera Álvarez, I. (2011). La catedral de Santiago en la época contemporánea: arte y arquitectura (1833-1923). Santiago de Compostela: Teófilo Edicións e Consorcio de Santiago.

Millán González-Pardo, I. (1990). Importantes descubrimientos en el mausoleo del Apóstol Santiago. Peregrino, 17, 18-20.

Monterroso Montero, J. (2004). A difícil arte de pintar. En Pintores composteláns: histopria e renovación entre os séculos XIX e XX. Santiago de Compostela: Consorcio de Santiago-Xunta de Galicia, 32-47.

Otero Túñez, R. (1997). La Edad Contemporánea. En La catedral de Santiago de Compostela. Santiago de Compostela: Caja de Ahorros de Santiago, 379-399.

Otero Túñez, R. (2004). José Ferreiro. En Artistas Galegos. Escultores. Tomo VII: Séculos XVIII e XIX. Vigo: Nova Galicia Edicións, 208-247.

Pérez de Urbel, J. (1952). Orígenes del culto de Santiago en España. Hispania Sacra, 5, 1-34.

Pérez Varela, A. (2016). Donaciones de platería de las reinas Mariana de Habsburgo y Mariana de Neoburgo en Santiago de Compostela y A Coruña. En Iberoamérica en perspectiva artística: transferencias culturales y devocionales. Castellò: Universitat Jaume I, 433-452.

Pérez Varela, A. (2018a). La platería civil compostelana en el tránsito del siglo XIX al XX a través de las fotografías inéditas del archivo personal del platero Ricardo Martínez Costoya. Quintana: revista de estudios do Departamento de Historia da Arte, 17, 317-336.

Pérez Varela, A. (2018b). Las piezas del platero Ricardo Martínez Costoya para el cardenal Martín de Herrera, Norba: revista de arte, 38, 247-263.

Pérez Varela, A. (2018c). Una aproximación a la figura del platero compostelano José Losada de Dios (ca. 1817-1887). En 'Yngenio e arte': elogio, fama y fortuna de la memoria del artista. Murcia: Fundación Universitaria Española, Murcia, 675-696.

Pérez Varela, A. (2019). Vida y obra del platero compostelano Ricardo Martínez Costoya (18591927): contexto, vida y obra. Universidade de Santiago de Compostela [tesis doctoral].

Pombo Rodríguez, A. (1999). O rexurdir do culto xacobeo e da peregrinación durante o pontificado do cardeal Miguel Payá y Rico (1875-1886). En Actas del V Congreso Internacional de Asociaciones Xacobeas. A Coruña: Diputación de A Coruña, 157-196.

Portela Pazos, S. (1953). Orígenes del culto al Apóstol Santiago en España. Arbor, 91-92, 455471.

Pugliese, C. (1999). Las peregrinaciones a Santiago de Compostela en el siglo XIX. En Santiago, Jerusalén, Roma: diario de una peregrinación a estos y otros santos lugares de España, Francia, Egipto, Palestina Siria e Italia en el año del jubileo universal de 1875. Santiago de Compostela: Constructora San José, 37-62.

Requejo Alonso, A. B. (2005). Los museos eclesiásticos de Galicia. Santiago de Compostela: Universidade de Santiago de Compostela.

Requejo Alonso, A. B. (2006). Da feira á exposición no ámbito local. Conservar, expoñer e mirar como condicións para o progreso. En Real Sociedade Económica de Amigos do País de Santiago de Compostela (1784-2006). Santiago de Compostela: Fundación Caixa Galicia, 143-153.

Rodríguez González, A. (1999). Notas para la historia de Compostela (1879-1975). En Compostela na Historia: redescubrimiento-rexurdimento. Santiago de Compostela: Xunta de Galicia, 25-36.

Rodríguez Lago, J. R. (1995). Os Outros Xacobeos. Anos Santos e Restauración na Igrexa Compostelá (1875-1898). En Historia Nova III. Contribución dos Xoves Historiadores. Santiago de Compostela: Asociación Galega de Historiadores, 205-226.

Rosende Valdés, A. (2013). Compostela (1780-1907): Una aproximación a la ciudad decimonónica. Santiago de Compostela: Consorcio de Santiago y Teófilo Edicións.

Sánchez Albornoz, C. (1971). En los albores del Culto Jacobeo. Compostellanum, 16/1-4, 37-71. Sánchez Cantón, F. (1956). Opúsculos gallegos sobre Bellas Artes de los siglos XVII y XVIII. Santiago de Compostela: Bibliófilos Gallegos. 
Seling, H. (1980). Die Kunst der Augsburger Goldschmiede 1529-1868. Munich: Meister, Marken, Werke, C. H.

Singul Lorenzo, F. (2001). La Ciudad de las Luces, arquitectura y urbanismo en Santiago de Compostela durante la Ilustración. Consorcio de Santiago: Santiago de Compostela.

Sousa, J., y Pereira, F. (1988). Historia de la Escuela de Artes y Oficios de Santiago. A Coruña: Editorial Diputación Provincial.

Suárez Otero, J. (2014): Locus Iacobi. Orígenes de un santuario de peregrinación. Universidade de Santiago de Compostela [tesis doctoral].

Taín Guzmán, M. (2006). El proyecto del canónigo José Vega y Verdugo para el sepulcro del Apóstol de la Catedral de Santiago. En Congresso Internacional do Barroco Ibero-Americano. Ouro Preto: C/Arte.

Taín Guzmán, M. (2008). Prolegómenos de una excavación en tiempos del canónigo José Vega y Verdugo: el mito de la cripta del apóstol Santiago y el retablo del arzobispo Gelmírez. Goya, 324, 200-216.

Varazze, I. (1987). La leyenda dorada, 2 vols. Madrid: Alianza [texto original: 1250-1280]).

Vidal Rodríguez, M. (1924). La tumba del Apóstol Santiago: ilustrada con cien fotograbados: Santiago de Compostela: Tipografía del Seminario Central.

Vigo Trasancos, A. (2010). Galicia no horizonte de 1909: cidades e arquitecturas para unha época de esplendor burgués. En Exposición galega de 1909: conmemoración do $1^{o}$ centenario da Exposición Regional Gallega, Santiago 1909. Santiago de Compostela: Consorcio de Santiago, Museo do Pobo Galego e Instituto de Estudos Galegos Padre Sarmiento, 31-78.

Villaamil y Castro, J. (1866). Descripción histórico-artística-arqueológica de la catedral de Santiago. Lugo: Imprenta de Soto Freire.

Vives, J. (1956). Bibliografía. Compostellanum, revista trimestral. Hispania Sacra, 9, 473-475.

Yzquierdo Peiró, R. (2017). Los tesoros de la Catedral de Santiago. Santiago de Compostela: Consorcio de Santiago-Teófilo Edicións.

Zepedano y Carnero, J. M. (1870). Historia y descripción arqueológica de la Basílica Compostelana. Lugo: Imprenta de Soto Freire. 